\title{
Cenozoic tectonic model of the Bohai Bay Basin in China
}

\author{
FUSHENG YU* \\ * State Key Lab of Petroleum Resources and Prospecting, China University of Petroleum, Changping, Beijing 102249, \\ China \\ $\ddagger$ Department of Earth Sciences, China University of Petroleum, Fuxue Road, Changping, Beijing 102249, China \\ $\S$ Hans Ramberg Tectonic Laboratory, Department of Earth Sciences, Uppsala University, Uppsala, Sweden
}

(Received 14 December 2015; accepted 7 May 2016; first published online 22 June 2016)

\begin{abstract}
Modelling results and seismic interpretation illustrate that the Cenozoic evolution of the Bohai Bay Basin (BBB) can be divided into different stages. A transtensional phase during Paleocene - early Oligocene time created NE-trending strike-slip faults and E-W-trending normal faults which were driven roughly by $\mathrm{N}-\mathrm{S}-$-extension, making an angle of $25^{\circ}$ with the strike-slip faults. Seismic data interpretation yields evidence that inversion phases occurred within the NE Xialiaohe Depression of the greater Bohai Bay Basin. This inversion phase is attributed to rotation and partial inversion that occurred during late Oligocene time, leading to formation of inversion structures along the NE part of Tanlu Fault. This episode is attributed to an anticlockwise rotation of the eastern part of the BBB driven by the convergence between the Pacific and Eurasian plates. The tectonic scenario described was simulated in scaled analogue models, which were extended by pulling two basement plates away from each other. Partial inversion was simulated by rotation of one of the plates relative to the other. Model results show many of the features observed in the BBB. Our model results are used to argue that, unlike the two-episode extension and whole-basin inversion models previously proposed for the $\mathrm{BBB}$, a single $\mathrm{N}-\mathrm{S}$-aligned extension followed by anticlockwise rotation accounts for the Cenozoic evolution of the BBB and produces some of the structural complexities observed in the basin.
\end{abstract}

Keywords: transtension, strike-slip, inversion, analogue modelling, Bohai Bay Basin.

\section{Introduction}

The Bohai Bay Basin (BBB), situated in the eastern part of the North China Platform, is one of the major petroliferous basins in China. It starts from north of Shenyang and terminates in the south around Kaifeng, and covers an area of about $200000 \mathrm{~km}^{2}$ with the Taihang Mountain to its west, the Yanshan Mountain to its north, the Luxi Uplift to its south and the Jiaoliao Uplift to its east (Tian \& Han, 1991; Tian, Han \& Xu, 1992; Allen et al. 1997) (Fig. 1). The basin has a total length of about $1000 \mathrm{~km}$, a maximum width of up to $400 \mathrm{~km}$ in its middle part, a width of 50 $100 \mathrm{~km}$ at its north and south extremities and a general NNE trend (Liu, 1987). The basin includes the northern part of the North China Plain, the marine Bohai Bay and the Xialiaohe Plain (Liu \& Liu, 1983; Ren et al. 2008; Gong et al. 2008; Qi, Zhou \& Wang, 2010). Based on the distribution of Paleocene deposits which have a variable thickness (2000-12000 m) (Liu, 1987; Ren et al. 2008; Qi, Zhou \& Wang, 2010) as well as tectonic features, the Bohai Bay Basin has been previously subdivided into six depressions and four uplifts (Chang, 1991; Tian \& Han, 1991; Allen et al. 1998). However, some authors (Guo et al. 2007; Qi \& Yang, 2010) have recently subdivided the whole basin into eight depressions and five uplifts/highs (Fig. 1). The eight depressions (Jizhong Depression,

$\dagger$ Author for correspondence: fushengyu@cup.edu.cn
JZD; Huanghua Depression, HHD; Jiyang Depression, JYD; Bozhong Depression, CBD; Linqing Depression, LQD; Changwei Depression, CWD; Liaodongwan Depression, LDWD; Xialiaohe Depression, XLHD) and five uplifts (Changxian Uplift, CXU; Xingheng Uplift, XHU; Chengning Uplift, CNU; Haizhong Uplift, HZU; Neihuang Uplift, NHU) are fault-bounded (Fig. 1).

Based on seismic interpretation and regional geological background, five different models have been proposed for the tectonic evolution of the Bohai Bay Basin during Cenozoic time (Fig. 2). Some workers (Li, 1980; Ye et al. 1985; Liu, 1987; Qi et al. 1995a, b, c; Hu et al. 2001; Xu et al. 2001) proposed a rift basin formed by NW-SE extension during Cenozoic time with little or no strike-slip displacement along the bounding Taihangshan and Tanlu faults (Fig. 2a). The rifting was attributed to NW-SE regional extension induced by mantle convection (Li \& Xue, 1980; Liu \& Liu 1983; Ma et al. 1983; Ma, Liu \& Su, 1984; Ye et al. 1985; Liu, 1987; Tian \& Han, 1991), India-Eurasia collision (Molnar \& Tapponnier, 1975; Yin, 2000; Liu, Cui \& Liu, 2004) or by roll-back of the subducted Pacific Plate (Ye, Zhang \& Mao, 1987; Northrup, Royden \& Burchfiel, 1995; Zhang et al. 2003; Schellart \& Lister, 2005, Guo et al. 2005). Another group of researchers (Klimetz, 1983; Mann et al. 1983; Nabelek, Chen \& Ye, 1987; Chen \& Nabelek, 1988) proposed a giant pull-apart basin model to emphasize the significance of strike-slip movements along the NE-trending faults (Fig. 2b). According to this model, the basin 


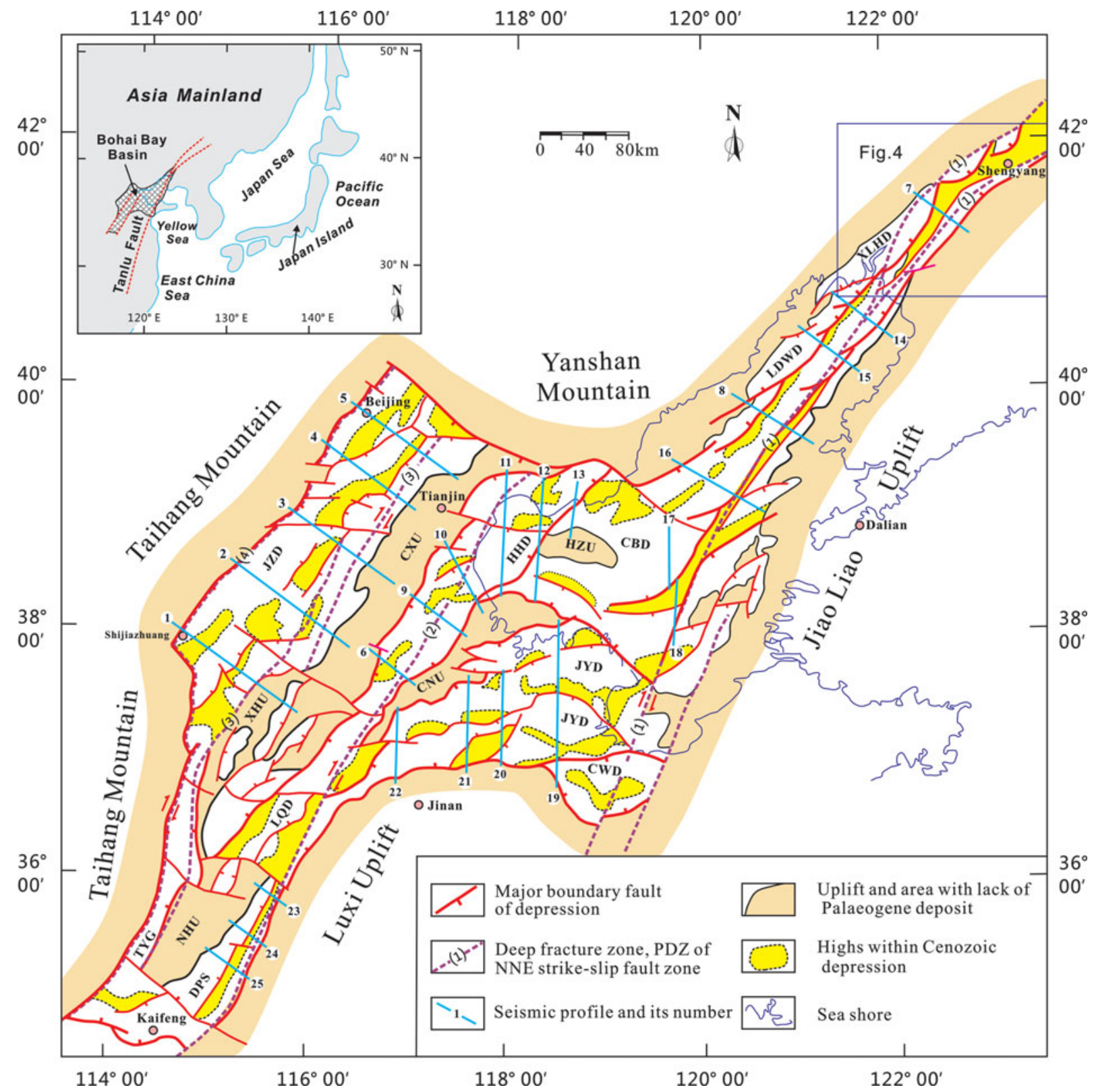

Figure 1. (Colour online) Cenozoic structural map of the Bohai Bay Basin showing the main elements (modified from Qi \& Yang, 2010). JZD - Jizhong Depression; HHD - Huanghua Depression; LQD - Linqin Depression; XLHD - Xialiaohe Depression; LDWD Liaodongwan Depression; JYD - Jiyang Depression; CWD - Changwei Depression; CBD - Central Bohai Depression; DPS - Dongpu Sag; TYG - Tangyin Graben; CXU - Cangxian Uplift; XHU - Xingheng Uplift; NHU - Neihuang Uplift; HZU - Haizhong Uplift; CNU - Chengning Uplift. (1) Shenyang-Weifang strike-slip fault zone; (2) the Huanghua-Dongming strike-slip fault zone; (3) the Baxian-Shulu-Handan strike-slip fault zone; and (4) Taihangshan strike-slip fault zone.

is due to right-lateral strike-slip movement along the NE-trending large-scale Taihangshan and Tanlu faults (Hu, 1982; Nabelek, Chen \& Ye, 1987; Hou, Qian \& Song, 1998; Hou, Qian \& Cai, 2001; Hsiao, Graham \& Tilander, 2004). The third model attributed formation of the basin to one phase of Cenozoic N-S extension due to the slab window effect caused by subduction of the ridge between the Kula and Pacific plates (Zhou \& Zhou, 2006; Zhou et al. 2009) (Fig. 2c). Two subsequent $\mathrm{N}-\mathrm{S}$ phases of dextral transtension scenarios were also proposed for the formation of the BBB (Fig. 2d). This includes early dextral transtension res- ulting in the formation of isolated rifts (e.g. JZD, LQD, JYD, HHD and XLHD) during Paleocene-Eocene time and a later extension during middle Eocene time, creating the Bozhong Depression (Allen et al. 1997, 1998). According to Allen et al. $(1997,1998)$, these two extension phases were followed by inversion due to $\mathrm{E}-\mathrm{W}$ compression. The fifth model proposed for the evolution of BBB (Fig. 2e) outlines a rift basin caused by NW-SE extension superimposed by dextral strike-slip movement along several steeply dipping faults. According to this model, extension from the middle Paleocene - late Oligocene period was induced by upwelling of 

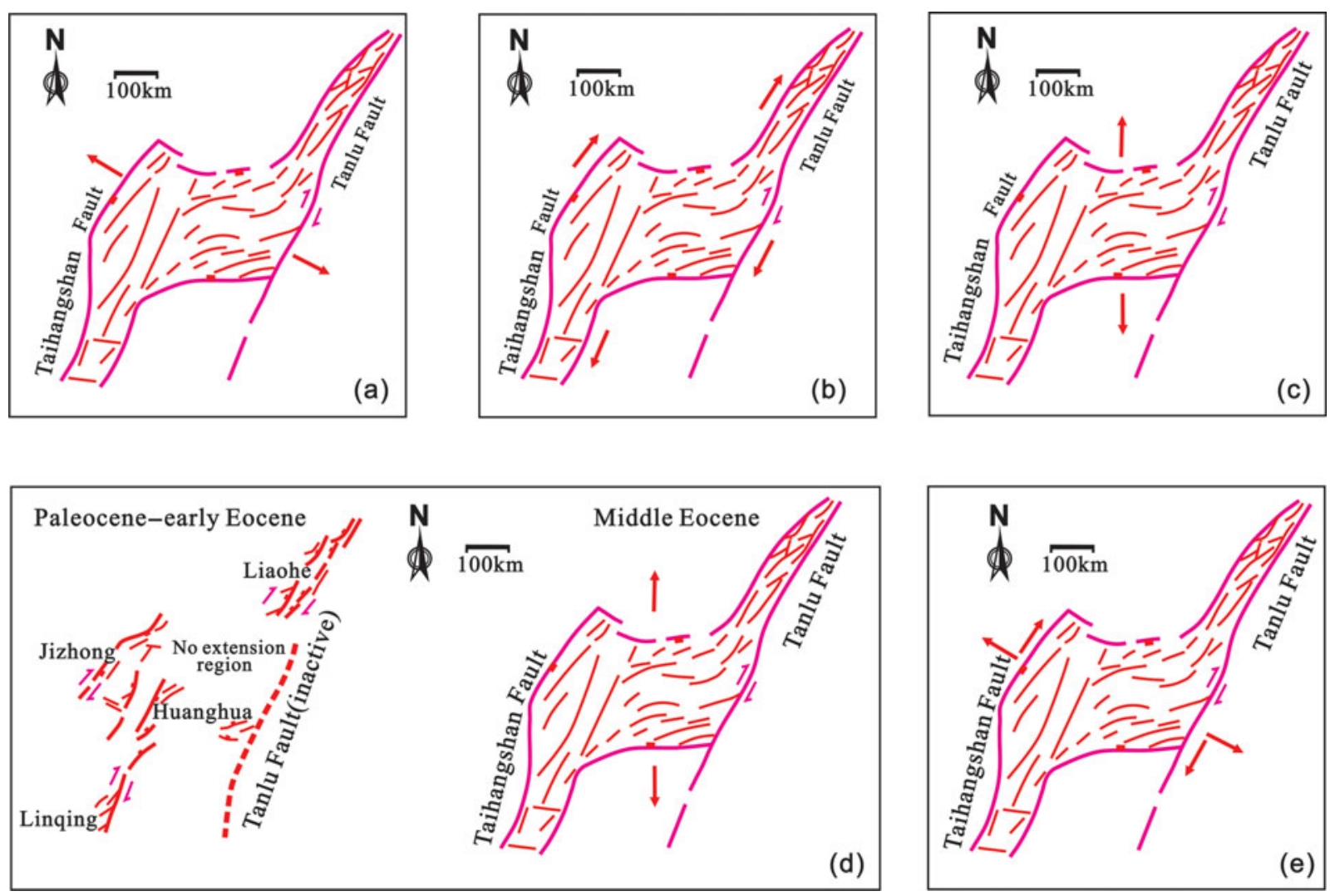

Figure 2. (Colour online) Different kinematic models proposed for the Bohai Bay Basin in Cenozoic. (a) Rift basin caused by NW-SE extension (Ye et al. 1985; Liu, 1987). (b) Giant pull-apart basin (Klimetz, 1983; Hou, Qian \& Song, 1998). (c) Rift basin caused by N-S extension (Zhou \& Zhou, 2006). (d) Two-phase dextral transtension basin (Allen et al. 1997, 1998). (e) Rift basin caused by NW-SE extension superimposed by dextral strike-slip (Qi \& Chen, 1992).

hot mantle material, whereas strike-slip deformation during Oligocene - Miocene time was probably related to a regional stress field induced by plate movement (Zhao, 1984; Wang, 1986; Qi \& Chen, 1992; Qi et al. 1994, 2008, 2013; Li, Lu \& Shi, 1995; Qi, 2004; Yu et al. 2007, 2015; Chen et al. 2010; Qi \& Yang, 2010; Li et al. 2015).

Inversion features in Neogene sediments are documented in the different parts of the BBB such as in the Xialiaohe, Jizhong and Jiyang depressions (Yang \& Wang, 1985; Wang, 1988; Hou et al. 2009). Some researchers (Zhao \& Windley, 1990; Hu, Wei \& Zhang, 2002; Su et al. 2009) have attributed these inversion structures to the $\mathrm{E}-\mathrm{W}$ compression caused by the collision of Australia with the Philippine Sea Plate. However, other authors (Chen et al. 2005; Ma, Qi \& Yu, 2005; Tong, Yu \& Geng, 2008; Li et al. $2010,2013)$ related the inversion features in the Xialiaohe Depression to Tanlu Fault dextral strike-slip movement.

Analogue modelling has been successfully used to simulate deformation in regions undergoing extension, and has proven to be a powerful tool in providing significant insights into the evolution of extensional regions (Corti, 2012). In this study, we present the results of a series of scaled analogue models to provide a different tectonic model for the evolution of the BBB and compare it to previous tectonic models proposed for the basin by other researchers. We also compare model results with seismic sections from the basin to validate our models.

\section{Geological setting}

The Cenozoic Bohai Bay Basin in east China developed on the pre-Tertiary strata and experienced two major tectonic evolution stages (Allen et al. 1997, 1998; Hou, Qian \& Cai, 2001; Hsiao, Graham \& Tilander, 2004, 2010; Yang \& Xu, 2004). During the syn-rift stage, Palaeogene strata including the Kongdian Formation (subdivided into three members), the Shahejie Formation (subdivided into four members) and the Dongying Formation (subdivided into three members) deposited on the faulted basement (Fig. 3). A series of half-grabens and full-grabens filled by non-marine clastic succession developed along major NE-, NEEand EW-trending fault systems (Huang \& Pearson, 1999; Yang \& Xu, 2004; Qi \& Yang, 2010). The thickness of the syn-rift sediments ranges from a few thousand of metres to a maximum thickness of $6 \mathrm{~km}$ in the Bozhong Depression (Liu, 1987; Qi, Zhou \& Wang, 2010). A thickness of $12 \mathrm{~km}$ has been reported in Jiyang Depression (Ren et al. 2008). During the post-rift thermal subsidence phase, Miocene and Quaternary 


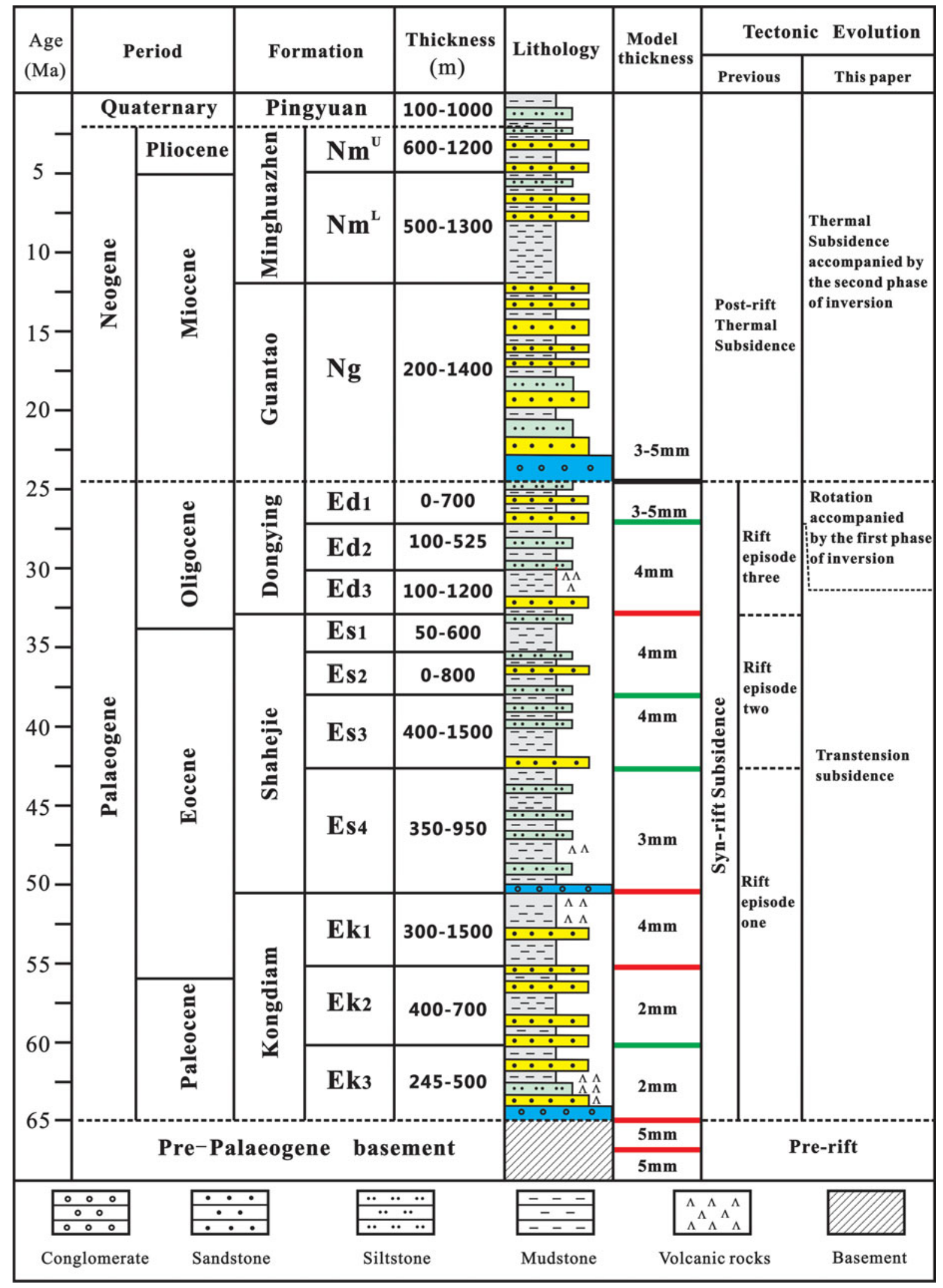

Figure 3. (Colour online) Generalized stratigraphy of the Bohai Bay Basin and the main tectonic phases (modified after Allen et al. 1997; Hu et al. 2001; Hao et al. 2010). Ek, Es, Ed, Ng and Nm denote Kongdian, Shahejie, Dongying, Guantao and Minghuazhen formations. 


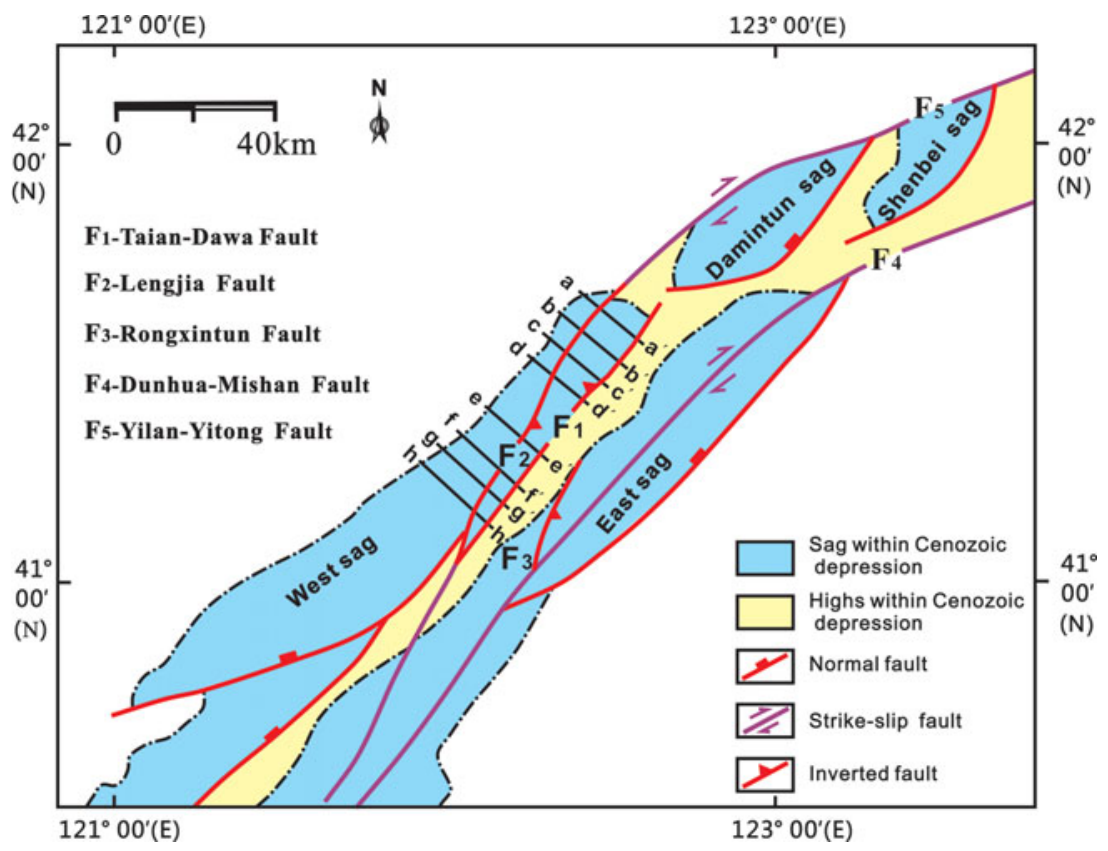

Figure 4. (Colour online) Cenozoic structural map of the Xialiaohe Depression in the NE part of Bohai Bay Basin showing the main structural elements and location of seismic sections shown in Figure 5 (modified from Qi et al. 2013). For location, see the inset in Figure 1.

strata including the Guantao, Minghuazhen and Pingyuan formations, which are up to $4000-5000 \mathrm{~m}$ thick, deposited over the whole basin covering the syn-rift successions which were separated by a regional unconformity above the Dongying Formation (Huang \& Pearson, 1999; Hu et al. 2001). Prior to the Guantao deposition, the upper part of the Dongying Formation was subjected to erosion, removing about 300 $900 \mathrm{~m}$ of sediments (Guo et al. 1998; Hu et al. 2001).

The elongate geometry of the Bohai Bay Basin is controlled by extensional fault systems which were mainly developed during middle Paleocene -late Oligocene time, and three strike-slip fault systems (Zhao, 1984; Wang, 1986; Qi \& Chen, 1992; Qi et al. 1994, 2008, 2013; Li, Lu \& Shi, 1995; Qi, 2004; Yu et al. 2007, 2015; Chen et al. 2010; Qi \& Yang, 2010; Li et al. 2015). The extensional fault systems consist of normal faults predominantly trending NE with different attitudes and oblique-slip faults trending NW and WNW. The extensional faults are confined by four NNE-trending right-lateral strike-slip faults including the Tanlu (the Shenyang-Weifang strike-slip fault zone), Lanliao (the Huanghua-Dongming strikeslip fault zone), Shulu-Handan (the Baxian-ShuluHandan strike-slip fault zone) and Taihangshan largescale fault zones (Fig. 1). The Tanlu and Taihangshan fault zones define the eastern and western boundaries of the basin, respectively. The other two fault zones, Lanliao and Shulu-Handan, are intrabasinal faults. Each strike-slip fault zone is composed of one or several principal strike-slip fault(s) with secondary structural elements indicating a dextral strike-slip movement (Qi \&
Yang, 2010). The structural styles of individual strikeslip zones may be different, and in some places an inversion deformation can be recognized in the NE part (the Xialiaohe Depression) of Tanlu Fault Zone (Chen et al. 2005; Tong, Yu \& Geng, 2008) (Figs 4, 5), whereas in other parts along the strike-slip zones steep strike-slip faults involved in basement exist (Zhu et al. 2012; Zhang et al. 2015). Such inversion structures, which developed locally in the Xialiaohe Depression, for example Lengiia reverse fault ( $\mathrm{Li}$ et al. 2013; Qi et al. 2013) and Rongxintun reverse fault (Chen et al. 2005), are clearly depicted on seismic data from the Xialiaohe Depression (Figs 4, 5).

The dynamics of the Bohai Bay Basin during Cenozoic time is highly debated. Applying the two-stage extension model of McKenzies (1978), the Bohai Bay Basin was thought to have experienced the Palaeogene rifting and differential subsidence and Neogene post-rift thermal subsidence (Li, 1980; Ye et al. 1985; Hu et al. 2001; Yang \& Xu, 2004; Feng et al. 2010) (Fig. 3). Based on this model, the basin is interpreted to be a Cenozoic rift basin driven by regional extension induced by mantle convection, or subduction of the western Pacific Plate (Allen et al. 1997, 1998; Northrup, Royden \& Burchfiel, 1995; Zhang et al. 2003; Yang \& Xu, 2004; Schellart \& Lister, 2005). Some authors emphasized the significance of strikeslip movements along the NNE-trending deep fracture zones (Hsiao, Graham \& Tilander, 2004) and interpreted the Bohai Bay Basin as a step-over strike-slip basin (Chen \& Nabelek, 1988) or a composite pullapart basin (Nabelek, Chen \& Ye, 1987), whereas others emphasize the role of delamination ( $\mathrm{He}$, Wang \& 

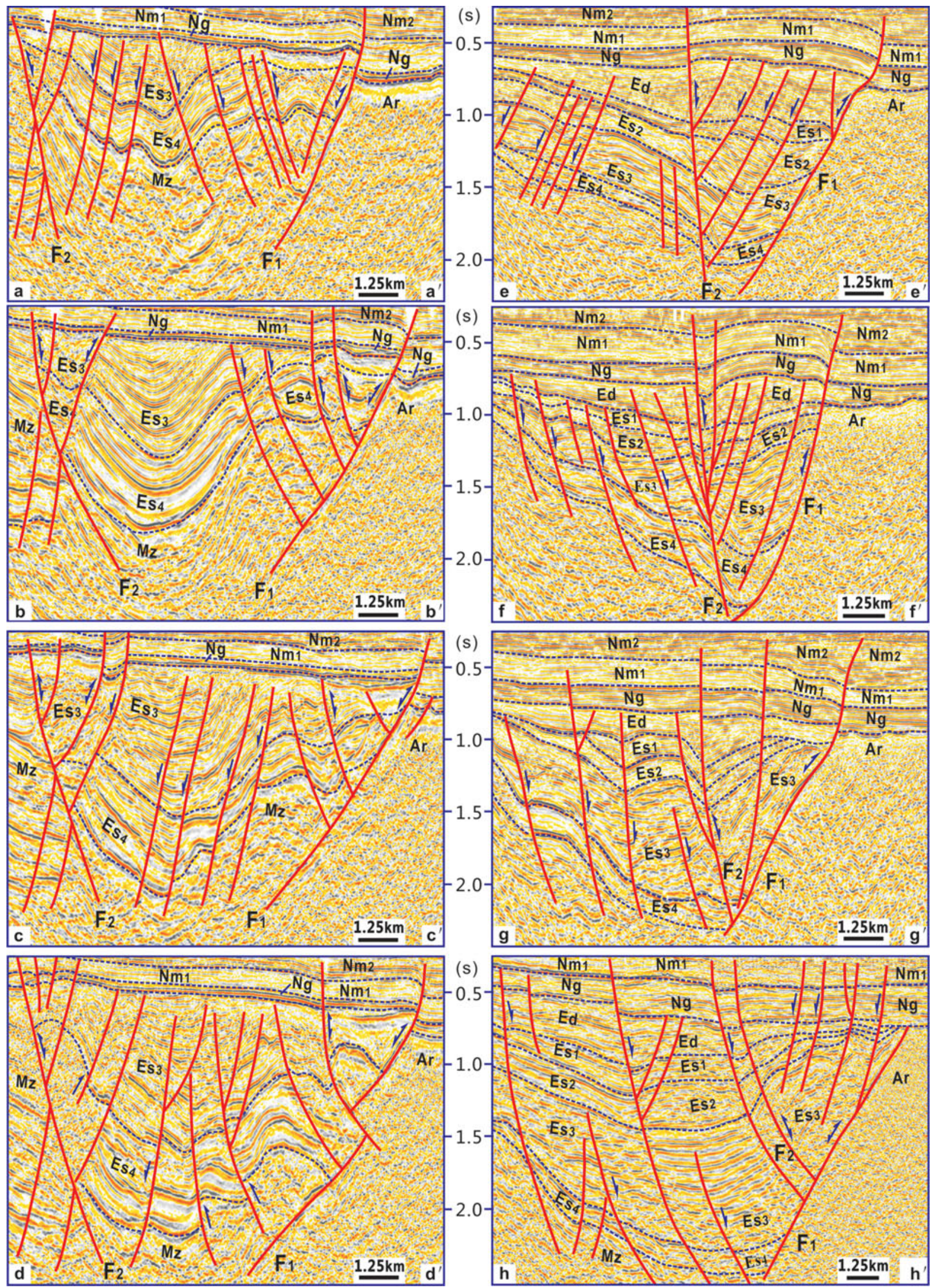

Figure 5. (Colour online) Interpretation of seismic profiles across the inversion areas of the western sag of Xialiaohe Depression (for section locations, see Fig. 4). $F_{1}$ is the Taian-Dawa Fault and $F_{2}$ is Lengjia Fault. 


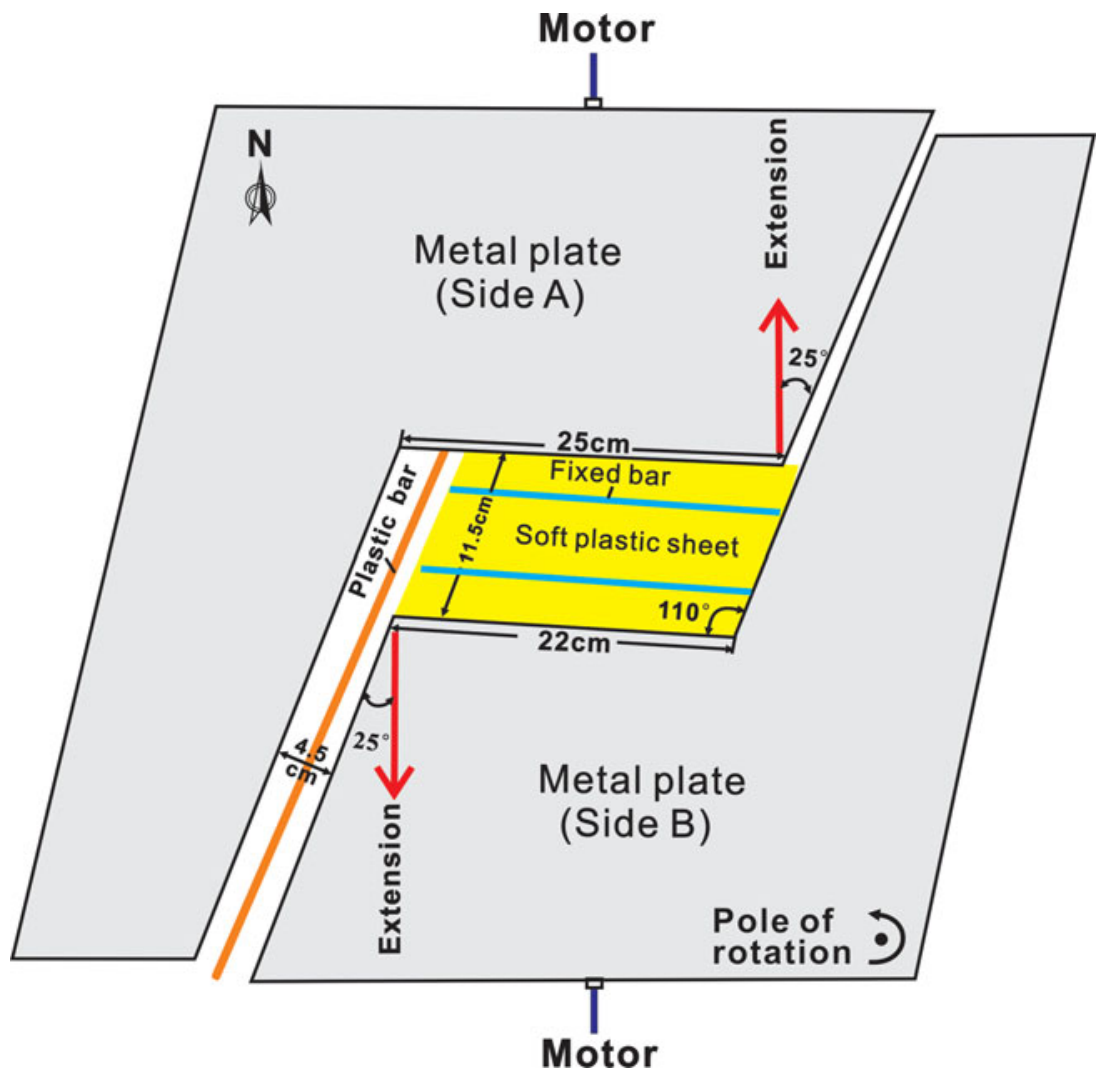

Figure 6. (Colour online) Model set-up showing plan view of basal metal plates used in the models.

Han, 1998; Zhang et al. 2001) or two-phase extension (Allen et al. 1997, 1998).

\section{Models}

\section{3.a. Set-up and kinematics}

In order to simulate the tectonic evolution of the Bohai Bay Basin, layers of sand were placed on two metal plates with releasing bend geometry (Fig. 6). Initially, the plates were placed next to each other in a way that the northern edges (right) were juxtaposed whereas the southern edges (left) were $4.5 \mathrm{~cm}$ apart. During deformation, these edges accommodated the extension by oblique slip. The two plates were displaced at an angle of $25^{\circ}$ oblique and divergent to the strike-slip margins (Fig. 6). In each experiment, a thin soft plastic sheet measuring $22 \mathrm{~cm} \times 11.5 \mathrm{~cm}$ in the step-over was glued beneath the plates to initiate extension. Two fixed bars measuring $22 \mathrm{~cm} \times 1 \mathrm{~cm}$ were placed on the soft plastic sheet to simulate the local topographic highs in the basement. A $1.5 \mathrm{~cm}$ wide plastic bar was placed in the middle of the west (left) strike-slip zone to facilitate the formation of a structural high. Such a plastic bar was not used in Model 4.

In all models, the basal plates were covered by two layers of loose sand (5 $\mathrm{mm}$ thick each) simulating prekinematic layers (Fig. 3). During extension, additional layers of sand were placed on the surface of the models in order to reproduce the stratigraphic succession in the BBB. The total thickness of the loose sand layers was $40 \mathrm{~mm}$ (Fig. 3).
During the model runs, the two basal plates were pulled away from each other in opposite directions by stepper motors at an average rate of $2 \mathrm{~cm} / \mathrm{h}$ (Fig. 6). The top surface of the models were photographed after every $2 \mathrm{~mm}$ of displacement and scanned with a laser after each $4 \mathrm{~mm}$ of displacement. The motors were stopped after a total of $5.6 \mathrm{~cm}$ extension. The results of five experiments (out of nine) with identical set-ups and initial bulk extension are described in this paper. However, after the initial bulk $5.6 \mathrm{~cm}$ extension, these five experiments were deformed differently. In Model 1, after an initial $\mathrm{N}-\mathrm{S}$ extension, basal plate $\mathrm{B}$ was rotated $8^{\circ}$ anticlockwise around a pole of rotation and the model was eroded. In Model 2, after an initial N$\mathrm{S}$ extension basal plate $\mathrm{B}$ was rotated $5^{\circ}$ anticlockwise around a pole of rotation without any erosion. In Model 3, after an initial N-S extension, both plates A and B were pushed towards each other in an $\mathrm{E}-\mathrm{W}$ direction, resulting in the inversion of the basins. This model simulated one of the proposed tectonic scenarios by Allen et al. $(1997,1998)$ where an E-W shortening was proposed. Model 4 experienced no rotation and erosion after an initial N-S extension. Model 5 was a test model to simulate one of the tectonic scenarios proposed by Ye et al. (1985) and Liu (1987), where they suggested a NW-SE extension without later inversion. This model was extended $5.6 \mathrm{~cm}$ in total in a NWSE direction without any later shortening (Table 1). At their final stages, all models were impregnated with water and serial vertical sections were sliced at $1 \mathrm{~cm}$ intervals and photographed. 
Table 1. Kinematics of models presented in this study

\begin{tabular}{lcccccc}
\hline Models & $\begin{array}{c}\text { Extension } \\
\text { direction }\end{array}$ & $\begin{array}{c}\text { Extension } \\
\text { amount } \\
(\mathrm{cm})\end{array}$ & $\begin{array}{c}\text { Shortening } \\
\text { direction }\end{array}$ & $\begin{array}{c}\text { Shortening } \\
\text { amount } \\
(\mathrm{cm})\end{array}$ & Rotation direction & $\begin{array}{c}\text { Rotation } \\
\text { amount } \\
\left({ }^{\circ}\right)\end{array}$ \\
\hline Model 1 & N-S & 5.6 & - & - & Anticlockwise & 8 \\
Model 2 & N-S & 5.6 & - & - & Anticlockwise & 5 \\
Model 3 & N-S & 5.6 & E-W & 1 & - & - \\
Model 4 & N-S & 5.6 & - & - & - & - \\
Model 5 & NW-SE & 5.6 & - & - & - & - \\
\hline
\end{tabular}

\section{3.b. Scaling}

The five models presented here are scaled to the BBB geometrically, kinematically and also dynamically. Geometric similarity was obtained by using a thickness ratio of approximately $2.5 \times 10^{-5}$ where $1 \mathrm{~cm}$ of loose sand in the models represents $2.5 \mathrm{~km}$ of sediments in nature. Kinematics similarity was achieved by simulating a sequence of events in the models that closely followed the interpreted evolution history in BBB. As such, based on our interpretation of seismic data and tectonostratigraphic relationships of different sedimentary formations, a two-stage evolution was proposed and mimicked in the models. In the first stage, models were extended in a $\mathrm{N}-\mathrm{S}$ direction initiating orthogonal extension in the greater BBB, but transtension along the northeastern and southwestern strike-slip faults. This extension/transtension stage is followed by an inversion stage resulting from anticlockwise rotation of the eastern block of BBB relative to its western block. However, in one model (Model 3) a full-scale inversion of the entire basin was simulated by shortening the model in an $\mathrm{E}-\mathrm{W}$ direction in order to test the tectonic model proposed by Allen et al. $(1997,1998)$. Sedimentation and erosion were simulated according to what the seismic profiles reveal.

Dynamic similarity was achieved by simulating the physical properties of the sedimentary units of BBB with appropriate modelling materials. In this respect the intrinsic material properties, such as the coefficient of cohesion $\left(\tau_{0}\right)$ and the coefficient of internal friction $(\mu)$, need to be approximated in the model and in nature (Koyi \& Peterson, 1993; Weijermars, Jackson \& Vendeville, 1993; Koyi, 1997). The angle of internal friction of rocks in the upper crust $(<10 \mathrm{~km})$ is averaged to $40^{\circ}$ (Brace \& Kohlstedt, 1980), which gives a coefficient of internal friction $(\mu)$ of 0.85 . The angle of internal friction of the uncompacted loose sand used in the models is $36^{\circ}$, giving a coefficient of internal friction of 0.73 (Koyi, 2001; Koyi \& Vendeville, 2003; Maillot \& Koyi, 2006), which is very close to rocks in the upper crust. Cohesion on the other hand is scaled by equality between the non-dimensional shear strength both in the model and nature:

$$
\left(\frac{\rho l g}{\tau_{0}}\right)_{m}=\left(\frac{\rho l g}{\tau_{0}}\right)_{\mathrm{n}}
$$

where $\rho$ is density, $l$ is length, $g$ is the acceleration due to gravity and subscripts $\mathrm{m}$ and $\mathrm{n}$ denote the model and nature, respectively. This non-dimensionalized ratio was calculated for model and nature using the shear strength of sedimentary rocks to range over 1-10 MPa (Hoshino et al. 1972). However, Schellart (2000) reported that values of cohesion of rocks in nature range over $20-110 \mathrm{MPa}$. For upper crustal rocks, we have taken the cohesion to be 10-20 MPa and the density to be $2550 \mathrm{~kg} \mathrm{~m}^{-3}$. Our loose sand acquired cohesion during scraping. Its cohesion is approximately $140 \mathrm{~Pa}$ and its density is $1550 \mathrm{~kg} \mathrm{~m}^{-3}$. These figures give the non-dimensional shear strength in equation (1) a value of 1.1 and 3.1-6.3 for model and nature, respectively. However, using higher cohesion for upper crustal rocks (e.g. $50 \mathrm{MPa}$ ) reduces the ratio for nature to 1.2, which is the same as that in the models. These two ratios, which are within the same order of magnitude, suggest that our models approximate dynamic similarity with their prototype.

\section{Model results}

\section{4.a. Plan view evolution}

During the initial phases of deformation in Model 1 ( 0 $0.8 \mathrm{~cm}$ transtensional displacement), dextral strike-slip faults $\left(f_{1}, f_{2}, f_{3}, f_{4}\right)$ developed along the model strikeslip boundary trending NE and four normal faults $\left(\mathrm{f}_{5}\right.$, $f_{6}, f_{7}, f_{8}$ ) were generated along the step-over boundary trending E-W to form two narrow grabens (Fig. 7).

With further extension (between $1.6 \mathrm{~cm}$ and $2.4 \mathrm{~cm}$ ), two new strike-slip faults $\left(\mathrm{f}_{9}, \mathrm{f}_{10}\right)$ parallel to strike-slip boundary developed in the SW part of the basin accompanied by two NE-trending, narrow grabens bounded by faults $\mathrm{f}_{1}$ and $\mathrm{f}_{2}$, respectively, separated by a horst. Three normal faults $\left(f_{11}, f_{12}, f_{13}\right)$ trending EW developed in the middle of the step-over areas bounding elongate $\mathrm{E}-\mathrm{W}$-trending grabens.

Left-stepping en échelon oblique extensional faults trending NE formed within the strike-slip fault zones during further extension $(3.2 \mathrm{~cm}$ to $5.6 \mathrm{~cm})$. Normal faults $f_{12}$ and $f_{13}$ propagated longitudinally across the centre of the step-over to create a new graben. The normal faults in the step-over area joined the strike-slip faults either through bending into the strike-skip faults or were 'truncated' by the strike-slip faults (Fig. 8a).

The $8^{\circ}$ anticlockwise rotation around a vertical axis, induced after $5.6 \mathrm{~cm}$ extension, resulted in inversion of the oblique faults $f_{3}$ and $f_{4}$ located within the strikeslip zone between newly formed thrust faults $t_{1}$ and 


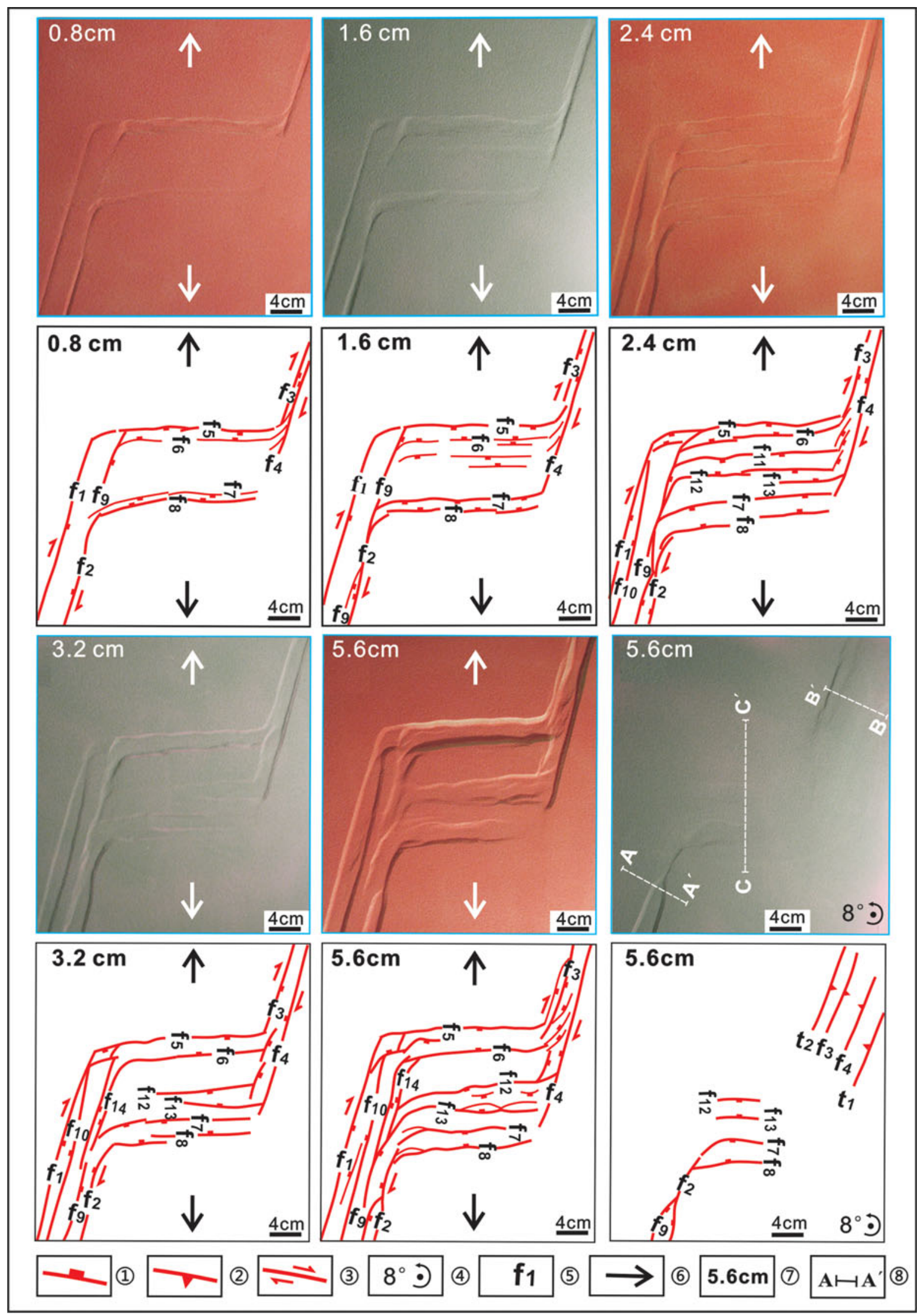

Figure 7. (Colour online) Plan view of different stages of the evolution of Model 1. Top: photographs and (Bottom), line drawing (1, normal fault; 2 , reverse fault; 3 , strike-slip fault; 4, rotation direction and amount; 5, interpreted fault number; 6 , move direction; 7, displacement; 8 , section location) 


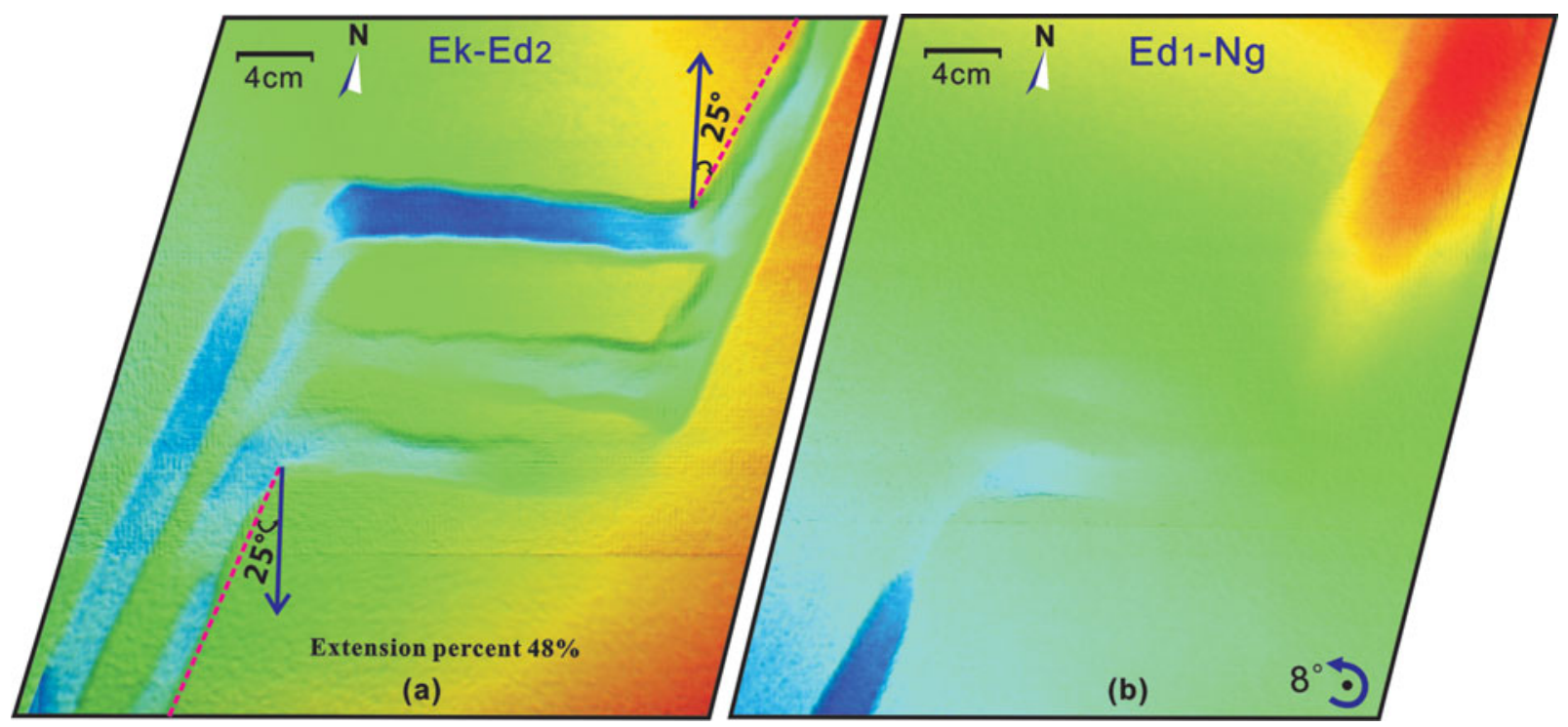

Figure 8. (Colour online) Scanned images of surface of Model 1 at (a) transtension stage (Paleocene - early Oligocene) and (b) rotation stage (late Oligocene) showing depressions (blue) and structural highs (red). Note in (b) the structural high in the NE and depression in the SW during rotation.

$t_{2}$. Strike-slip faults $\left(f_{2}, f_{9}\right)$ and normal faults $\left(f_{7}, f_{8}\right.$, $f_{12}, f_{13}$ ) stayed active due to oblique-slip (Fig. 7), albeit with a lower amount of displacement, locally forming shallow grabens (Fig. 8b).

The transtensional evolution of Model 2 (from start up to $5.6 \mathrm{~cm}$ extension) and its inversion afterwards is similar to Model 1 (Fig. 9). However, inversion of Model 3 was initiated by shortening the model in an EW direction, which was different from that of Model 1 where inversion was initiated due to anticlockwise rotation of the southeastern block relative to the northwestern block. Inversion in Model 3 developed along the northeastern strike-slip faults to generate thrust faults $t_{1}, t_{2}$ and inverted pre-existing normal faults such as $\mathrm{f}_{3}, \mathrm{f}_{4}$. The roughly $\mathrm{E}-\mathrm{W}$-trending pre-existing normal faults within the step-over area $\left(f_{5}, f_{6}, f_{7}, f_{8}, f_{12}, f_{13}\right)$ were reactivated during this $\mathrm{E}-\mathrm{W}$-shortening as strikeslip faults with some normal dip slip, resulting in formation of shallow grabens (Fig. 9).

Model 4 has a similar deformation history as Model 1 , but did not include a stationary segment at the base of the SW transtension zone (between Taihangshan and Lanliao strike-slip faults in nature). Dextral strike-slip boundary faults $\left(f_{1}, f_{2}, f_{3}, f_{4}\right)$ developed along the model boundary trending NE, and six normal faults $\left(\mathrm{f}_{6}, \mathrm{f}_{7}, \mathrm{f}_{8}\right.$, $f_{11}, f_{12}, f_{13}$ ) trending EW were generated along the stepover boundary to form three narrow grabens (Fig. 10). Unlike Model 1, in this model no narrow graben formed between the strike-slip faults in the SW transtension zone (faults $f_{9}$ and $f_{14}$ in Model 1) (Figs 7, 10). The normal faults trending E-W died out at the western end and bent into the strike-slip faults at the eastern end. The horst between faults $f_{9}$ and $f_{10}$ was wider than that in Model 1. No inversion was induced in this model, which was not subjected to compression and rotation.

Model 5 simulated one of the tectonics scenarios proposed by Ye et al. (1985) and Liu (1987), who suggested a NW-SE extension without later inversion. As such, this model was extended $5.6 \mathrm{~cm}$ in total in a NW-SE direction resulting in a different deformation pattern compared to the other four models. Normal boundary faults $\left(f_{1}, f_{2}, f_{3}, f_{4}\right)$ trending NNE were generated within both the step-over part of the basin and Xialiaohe and Dongpu areas during extension (Fig. 11a, b). Right-stepping en échelon faults $\left(f_{5}, f_{6}, f_{7}, f_{8}, f_{9}\right.$, $f_{10}, f_{11}$ ) trending ENE formed two sinistral obliqueslip fault zones along the northern and southern model boundary. Within the step-over area, a number of NNEtrending normal faults $\left(\mathrm{f}_{12}, \mathrm{f}_{13}, \mathrm{f}_{14}, \mathrm{f}_{15}, \mathrm{f}_{16}, \mathrm{f}_{17}, \mathrm{f}_{18}, \mathrm{f}_{19}\right)$ formed several grabens. No inversion was observed in this model.

\section{4.b. Vertical sections}

Photographs of vertical sections taken from the same location in models 1,2 and 3 were used to interpret the internal geometry of the models. In the southwestern part, two narrow grabens were separated by one horst formed between the boundary strike-slip faults $f_{1}$ and $\mathrm{f}_{2}$ during the transtension stage (Fig. 12). During the rotation stage in models 1 and 2 however, faults $f_{2}$ and $f_{9}$ were reactivated and formed a narrow graben (Fig. 12a-d). Faults $f_{1}$ and $f_{10}$ in Model 1 were also reactivated during this rotation stage, forming a more subtle graben (Fig. 12a, b). However, in Model 3 the graben-bounding faults were inverted during the $\mathrm{E}-\mathrm{W}$ shortening (Fig. 12e, f). During this inversion, the dip of fault $f_{2}$ became gentler upwards (Fig. 12e, f).

In the northeastern part in all three models, a narrow graben formed during the transtension stage between the boundary strike-slip faults $\mathrm{f}_{3}$ and $\mathrm{f}_{4}$ (Fig. 13). However, the models showed different inversion structures. Models 1 and 3 show some similarities, but are different from Model 2. In Model 2, no new thrust faults formed 

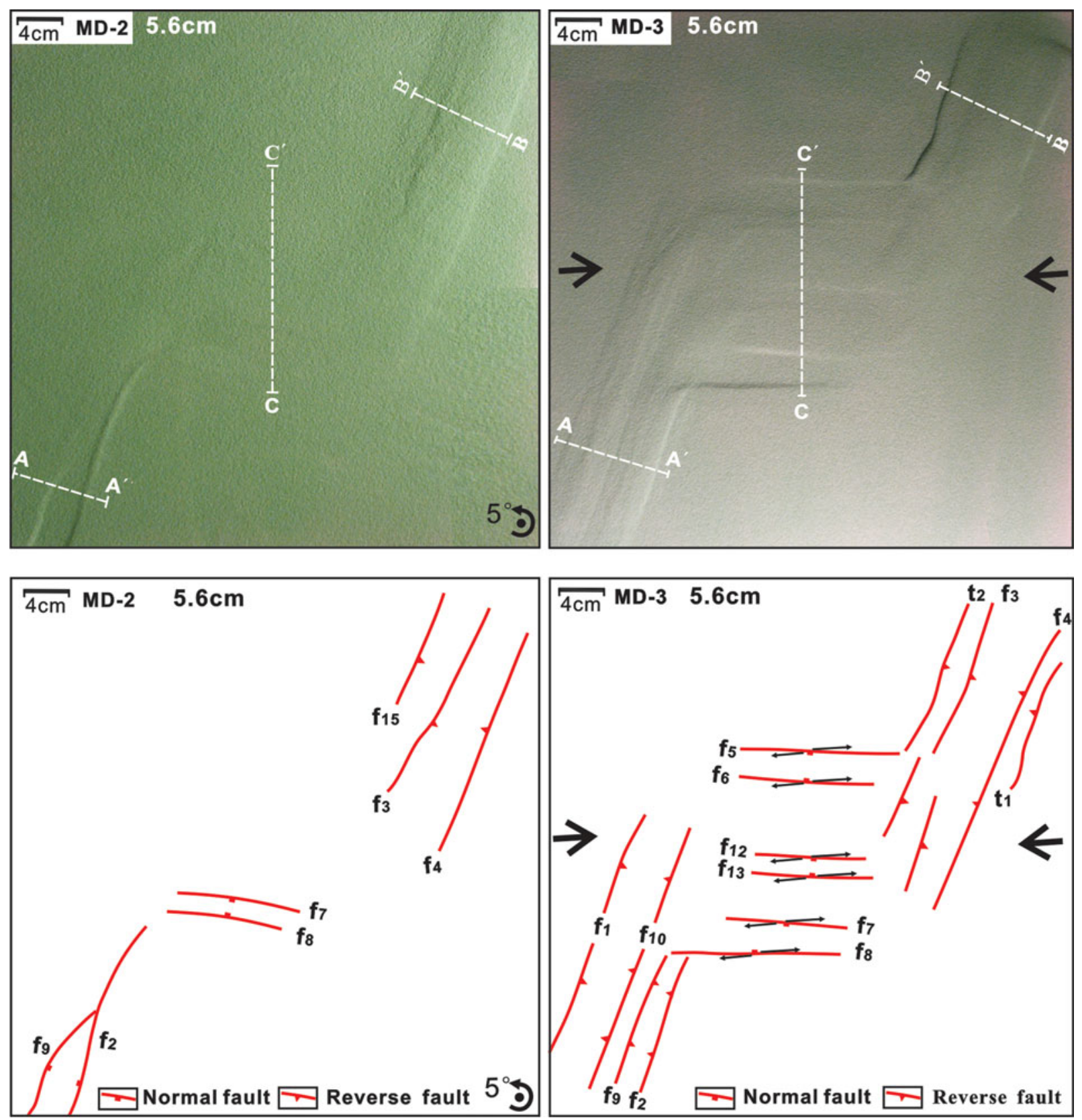

Figure 9. (Colour online) Plan view photographs and interpretation of the final stage (5.6 cm transtension) of Model 2 (left) and Model 3 (right). The dashed lines show the location of the sections shown in Figures 12-14.

during $5^{\circ}$ anticlockwise rotation. The shortening due to this rotation was accommodated by inversion of the pre-existing, graben-bounding faults $\left(f_{3}\right.$ and $\left.f_{4}\right)$. The width of the inverted area was about $6 \mathrm{~cm}$. In models 1 and 3 on the other hand, in addition to inversion along the pre-existing, graben-bounding faults, two thrusts formed. As a result, the inverted area widens upwards (width of inversion zone above the graben in models 1 and 3 was about $10 \mathrm{~cm}$ ). One of the thrusts in Model $1\left(t_{2}\right)$ used and inverted the lower segment of the preexisting normal fault but became gentler at shallower level (Fig. 13a, b). All the thrusts solely link to the strike-slip fault at deeper levels.

Within the step-over area, symmetric grabens and horsts bounded by steeply dipping faults were formed (Fig. 14). Some of these faults intersected each other at depth (section $\mathrm{CC}^{\prime}$ in Fig. 14a, b). Some subordinate faults cutting through the lower layers of the horsts developed to form narrow grabens.

\section{Discussion}

\section{5.a. Comparison between model results and nature}

The four transtensional models produced the broadly similar rhomboidal basin in plan view (Figs 7, 9, 10). This basin, which is bounded by strike-slip faults at its east and west margins, mimics some of the main features of the Bohai Bay Basin.

Model results at the final stage of extension are compared to the structural map of the BBB after the Paleocene - early Oligocene extension stage. This tectonic 

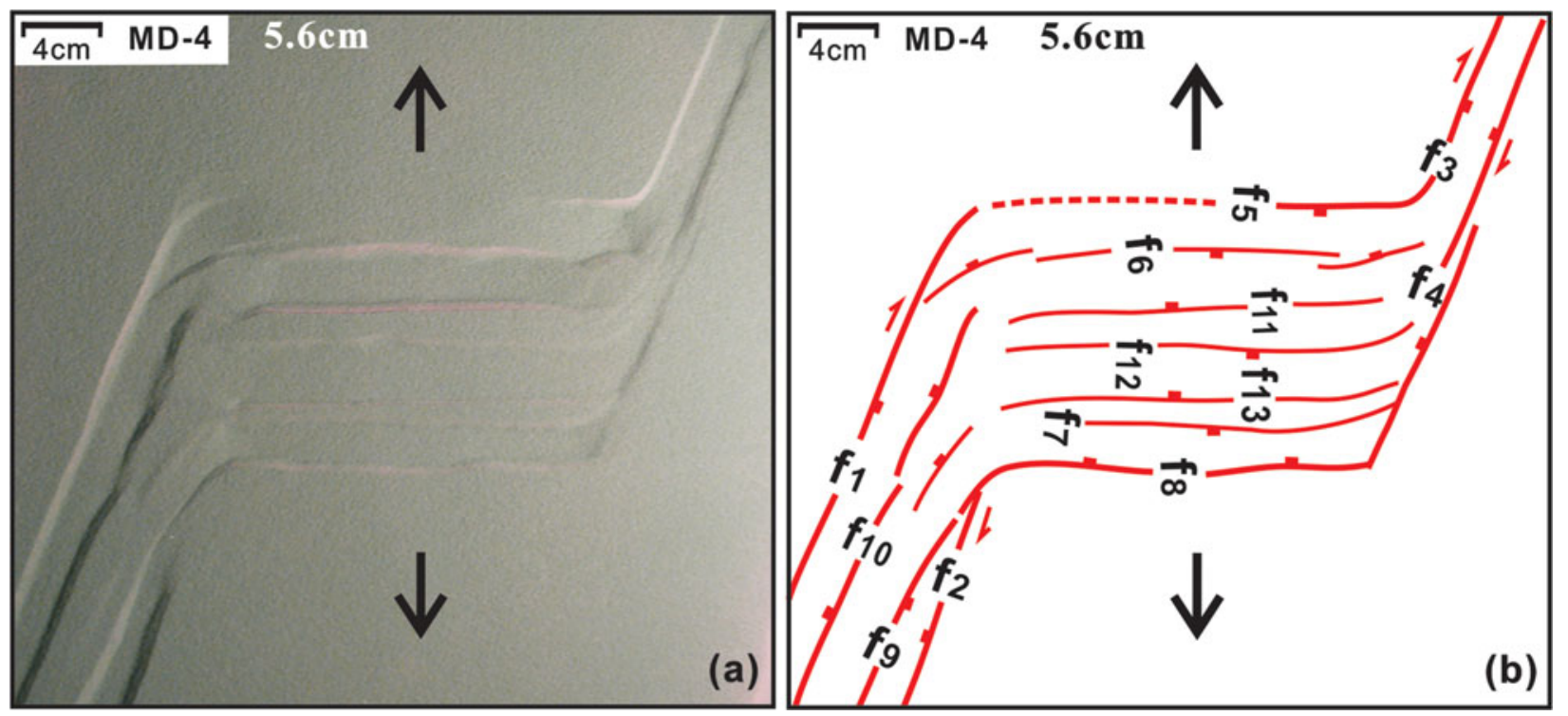

Figure 10. (Colour online) (a) Plan view photograph and (b) interpretation of the final stage (5.6 cm transtension) of Model 4.
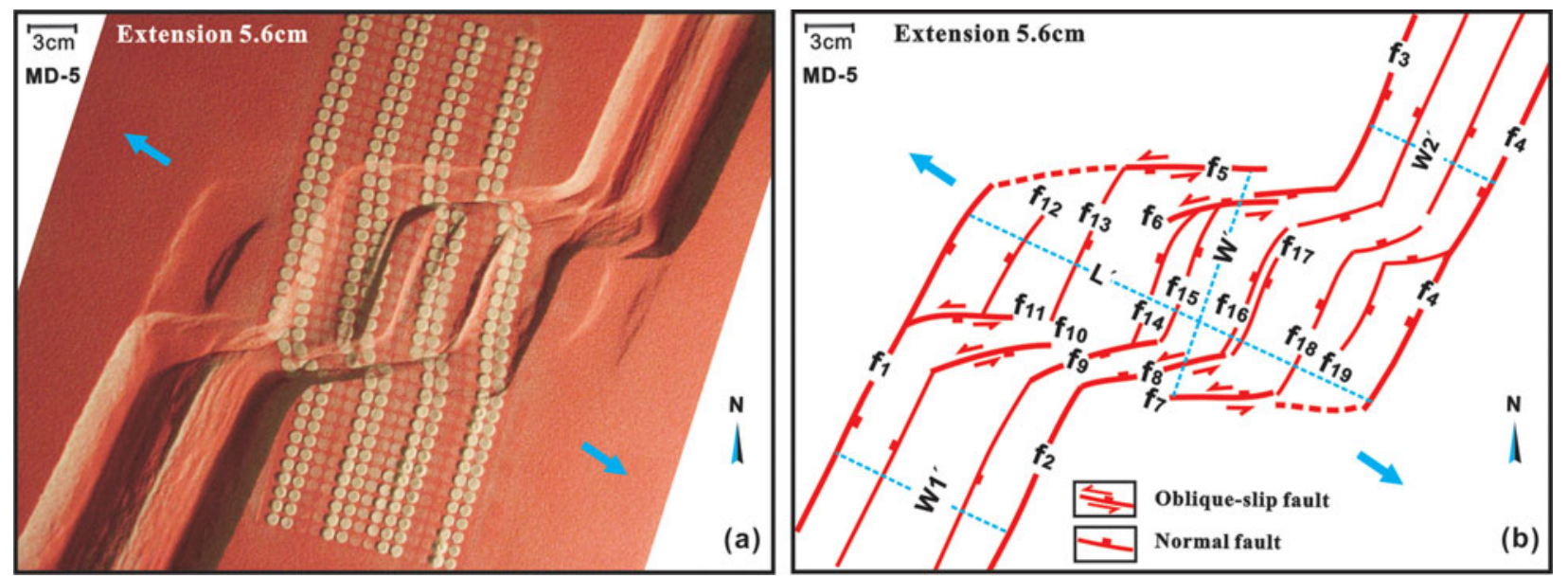

Figure 11. (Colour online) (a) Plan view photograph and (b) interpretation of Model 5 after $5.6 \mathrm{~cm} \mathrm{NW-SE} \mathrm{extension.} \mathrm{Note} \mathrm{that} \mathrm{the}$ normal faults are trending NNE and the strike-slip/oblique faults trend ENE.

map does not include the inversion stage. Accordingly, the inversion stage in the models was compared to Liaohe area where compression structures are observed on seismic profiles. Below, we compare the results of each model to observations from the BBB in order to test the different proposed tectonic scenarios and determine which of the models correctly simulate the basin.

Model 1, which included the full estimated kinematics of the $\mathrm{BBB}$, is used to outline the structural details of the BBB. Distribution and orientation of both the strike-slip fault zones (such as the Shenyang-Weifang, the Huanghua-Dongming, the Baxian-Shulu-Handan and the Taihangshan) and the major normal faults separating the depressions and structural highs (Figs 1, $15 \mathrm{a})$ in the Bohai Bay Basin are reproduced in the models although in a simplified way (Fig. 15b). The normal faults that intersected the strike-slip faults at the end with acute angles indicate that the dextral transtensional displacements took place.
Dimensions of the basal plates were estimated by roughly restoring the step-over area of the BBB to preextension state. During model runs, the models were extended to about $48 \%$ which is close to the rough estimation of the bulk extension (27-45\%, Table 2) in the Jiyang Depression of the BBB. The final dimensions (width $W$ and length $L$ ) of the models and the BBB show a good degree of similarity. The ratio $(L / W=1.30)$ in the step-over area of the BBB is close to the ratio of the model step-over area $\left(L^{\prime} / W^{\prime}=1.40\right)$. In addition, the width ratio of the basins in the NE and SW parts of the models $\left(W_{1}{ }^{\prime} / W_{2}{ }^{\prime}=1.94\right)$ show similar ratios to those in the $\operatorname{BBB}\left(W_{1} / W_{2}=1.92\right)$.

Model 1 also shows similarity in distribution and configuration of structural lows and highs with those developed in the Bohai Bay Basin (Fig. 15). The leftstepping en échelon oblique extensional faults within the NE part of the basin simulate similar features in the Xialiaohe (XLHD) and Liaodongwan (LDWD) depressions. However, the Haizhong uplift (HZU) and 

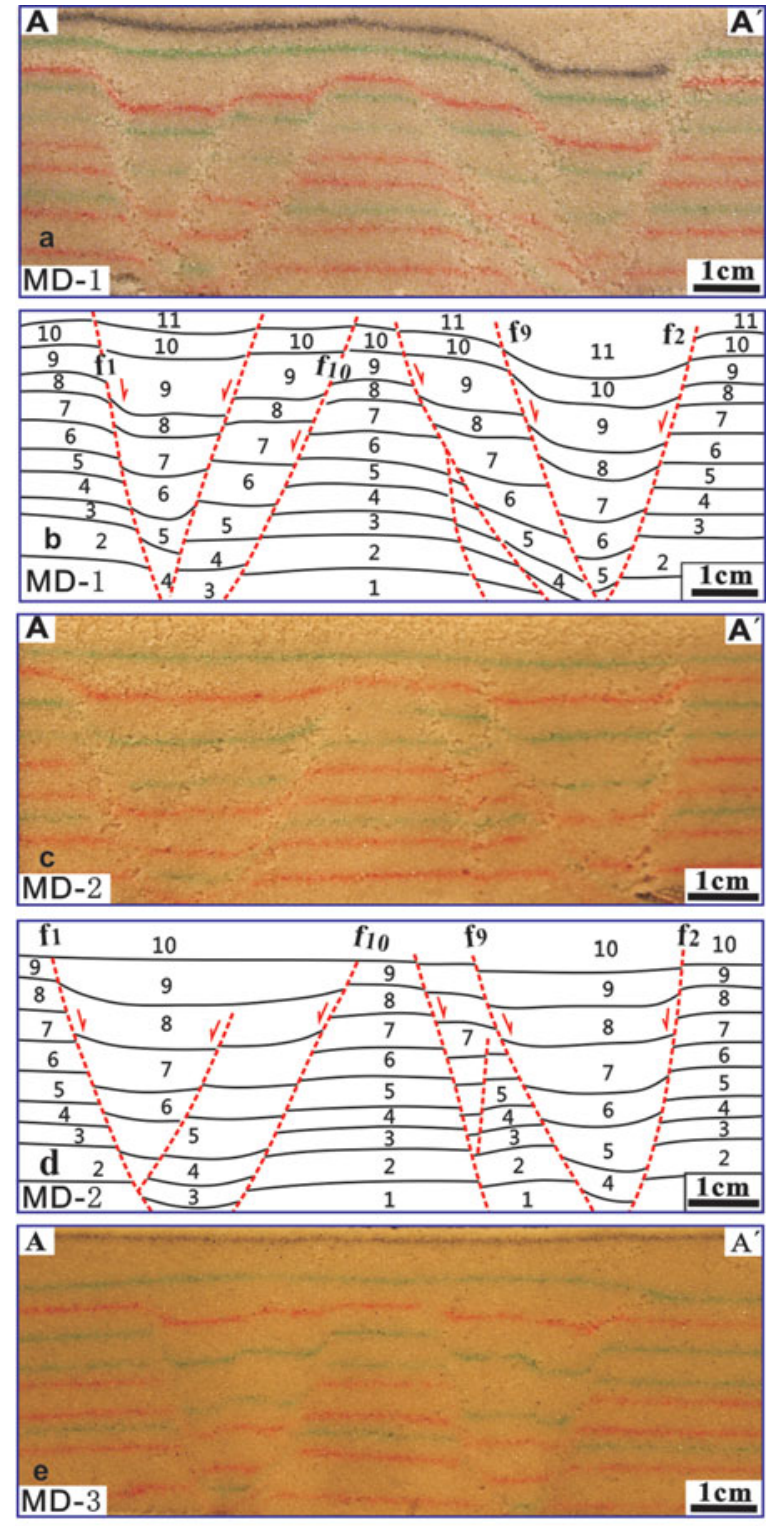

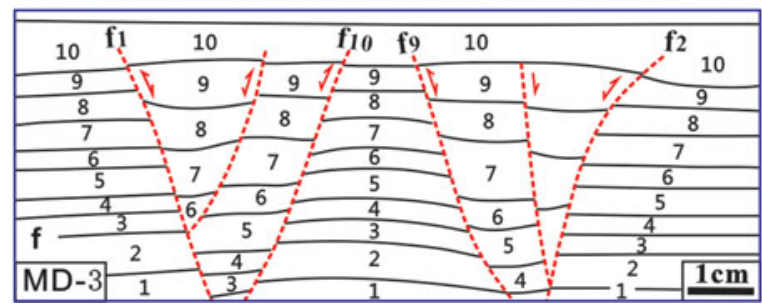

Figure 12. (Colour online) Vertical sections and interpretations of models 1, 2 and 3 across the Dongpu Sag in the SW part of the models (for location of sections see Figs 7, 9).

Changwei Depression (CWD) show a different dimension in the models compared to those seen in the BBB.

\section{5.b. Extension calculation}

In order to estimate the total amount of Cenozoic extension for different units of the Bohai Bay Basin, a variety of methods such as balanced section restorations (Liu, 1988; Li \& Li, 1994; Xiao, Chen \& Li, 2002; Jiang et al. 2007; Cao, 2008; Dong et al. 2013), trigonometric algorithm (Tian \& Han, 1990) and
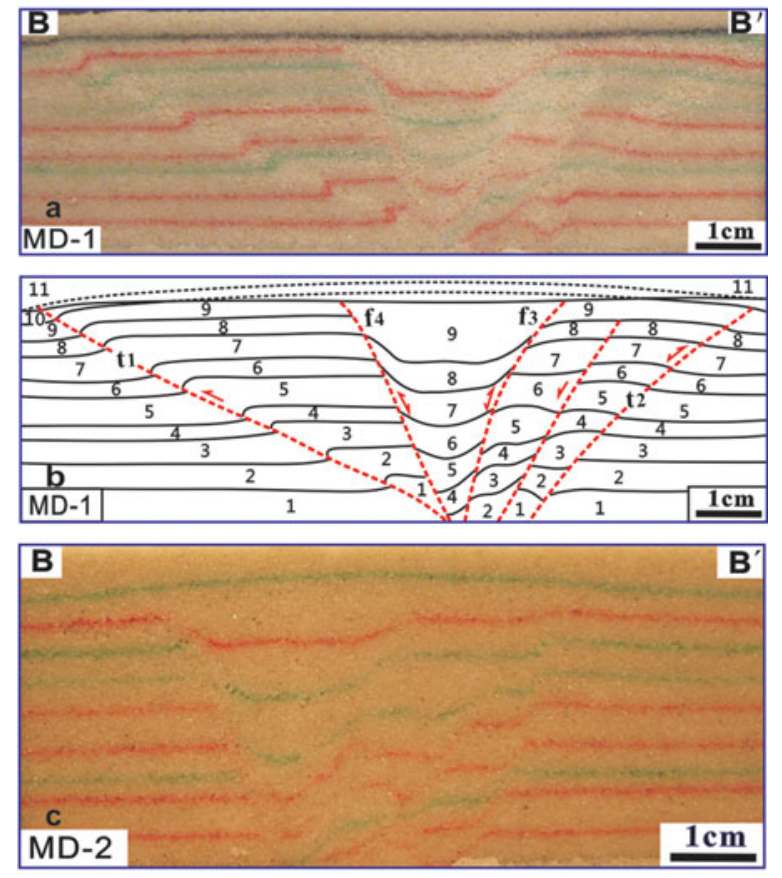

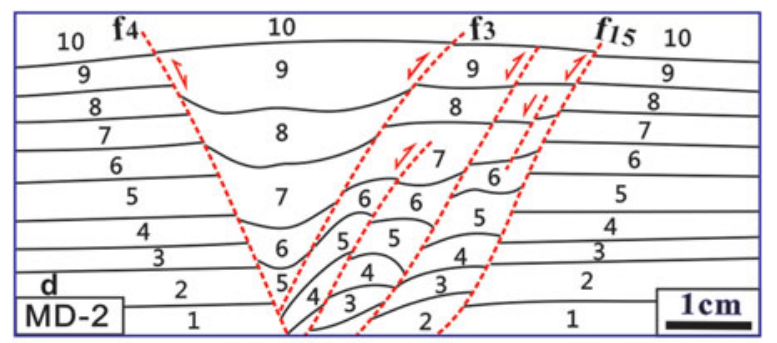
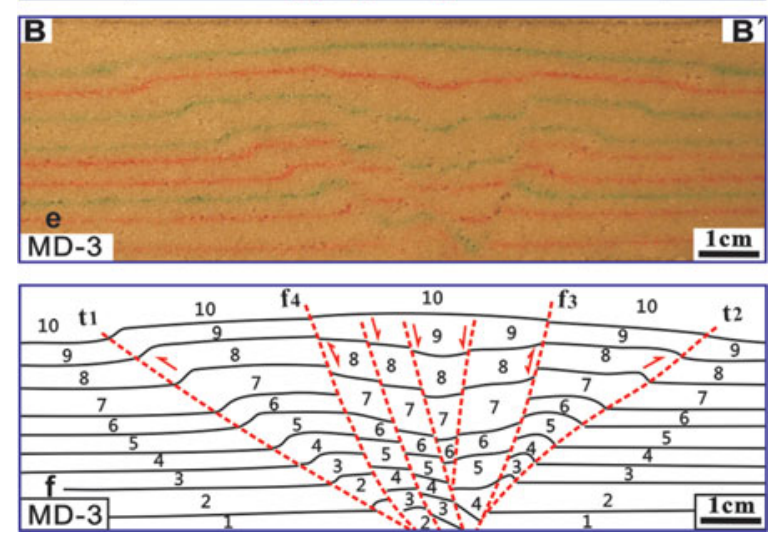

Figure 13. (Colour online) Vertical sections and interpretations of models 1, 2 and 3 across the Xialiaohe Depression in the NE part of the models (for location of sections see Figs 7, 9).

calculations of the $\beta$ factor applying the method of Jackson \& White (1989) (Allen et al. 1997) have been used. All of these analyses show that the extension ranges over 9.0-44.5\% (Table 2). The average extension of the Jizhong, Huanghua and Jiyang depressions, Dongpu Sag and Tanlu Fault Zone is about 29.78\%, $19.84 \%, 36.85 \%, 31.97 \%$ and $21.17 \%$, respectively. The maximum extension of the Jiyang Depression (c. $44 \%$ ) and Dongpu Sag (c. $34 \%$ ) are relatively larger than in other places within the greater BBB. Bulk extension across the Xialiaohe Depression of the NE part of the BBB calculated from restored seismic section reaches up to $29 \%$ in some places. These figures do 
C

$1 \mathrm{~cm}$
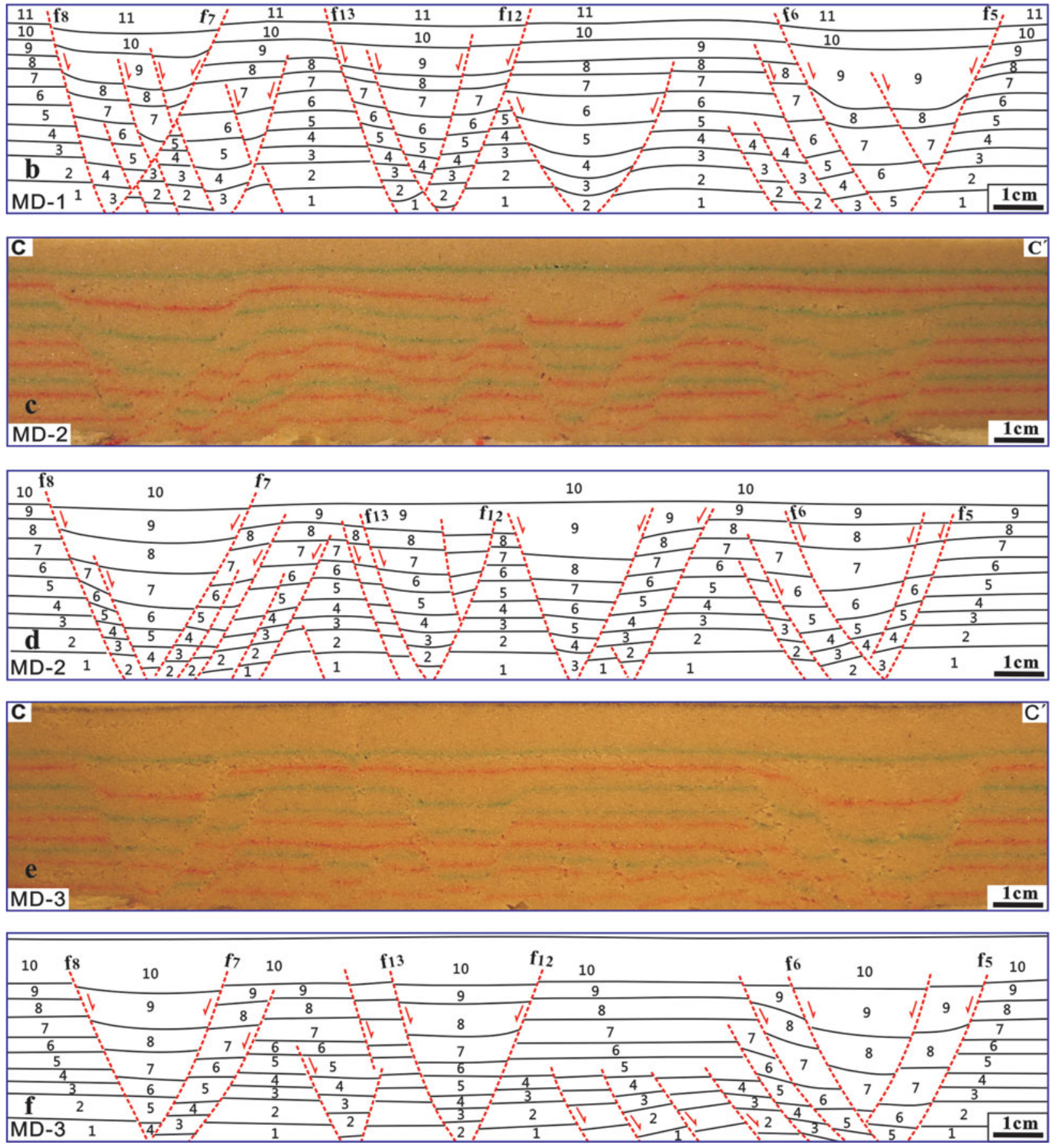

Figure 14. (Colour online) Photographs and line drawing of three vertical sections (C-C') of models 1, 2 and 3 across the step-over area (for location of sections see Figs 7, 9). 

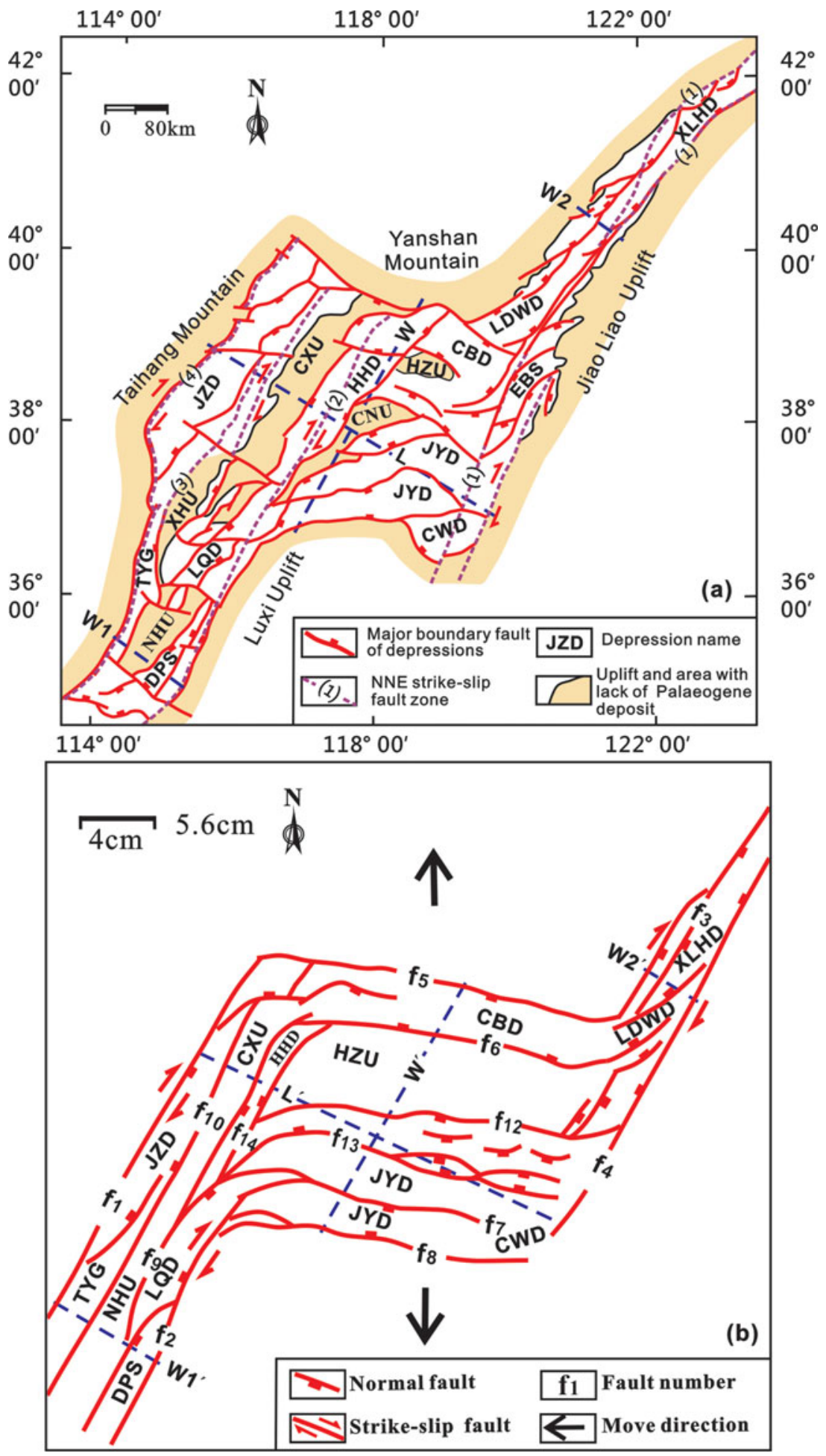

Figure 15. (Colour online) (a) Cenozoic structural tectonic map of the Bohai Bay Basin showing the main structural elements (modified from Qi \& Yang 2010). Fault names are the same as in Figure 1. (b) Line drawing of mapview of Model 1 at the end of extension (at $5.6 \mathrm{~cm}$ transtension).

not necessarily represent the bulk extension across the larger BBB due to the lack of regional seismic sections across the entire basin. Extension in the models was slightly larger $(48 \%)$ before block rotation and partial inversion. However, the total extension percentage across the southwestern and northeastern strikeslip zones was calculated by comparing initial and final widths. Total extension percentage across the southwestern strike-slip zone between faults $f_{1}$ and $f_{2}$ is about $41 \%$, which is slightly higher than that in the Dongpu Sag. Total extension across the northeastern strike-slip zone between faults $\mathrm{f}_{3}$ and $\mathrm{f}_{4}$ is about $33 \%$. In general, the amount of extension in the models is higher than that in nature, but still relatively close. The difference 
Table 2. Extension estimates of different depressions in BBB (for locations of seismic profile, see Fig. 1). ND - no deposition of Kongdian Formation and the fourth member of Shahejie Formation.

\begin{tabular}{|c|c|c|c|c|c|c|c|}
\hline Seismic profile & $\mathrm{EK}+\mathrm{ES}_{4}$ & $\mathrm{ES}_{3}$ & $\mathrm{ES}_{2+1}$ & Ed & $\mathrm{Ng}$ & Total extension & Extension $(\%)$ \\
\hline \multicolumn{8}{|c|}{ Extension amount of Jizhong Depression (km) } \\
\hline 1 & 11.4 & 9.2 & 1.4 & 1.0 & 0 & 23.0 & 37.7 \\
\hline 2 & 6.8 & 4.4 & 5.0 & 0.8 & 0 & 17.0 & 28.0 \\
\hline 3 & 14.0 & 3.6 & 0.6 & 0.2 & 0 & 18.4 & 18.0 \\
\hline 4 & 8.5 & 7.6 & 1.2 & 0.7 & 0 & 18.0 & 41.0 \\
\hline 5 & 3.0 & 5.6 & 1.2 & 0.1 & 0 & 10.7 & 24.2 \\
\hline \multicolumn{8}{|c|}{ Extension amount of Huanghua Depression (km) } \\
\hline 6 & 2.9 & 1.5 & 1.2 & 1.3 & 0.0 & 6.9 & 17.00 \\
\hline 9 & 16.06 & 0.10 & 2.08 & & 0.87 & 19.11 & 37.26 \\
\hline 10 & ND & 5.63 & 3.97 & & 1.42 & 11.02 & 13.96 \\
\hline 11 & ND & 3.35 & 9.42 & & 3.86 & 17.76 & 13.28 \\
\hline 12 & ND & 3.06 & 5.84 & & 5.04 & 13.39 & 11.43 \\
\hline 13 & ND & 3.58 & 4.63 & & 2.69 & 10.89 & 26.15 \\
\hline \multicolumn{8}{|c|}{ Extension amount along Tanlu Fault (km) } \\
\hline 7 & 0.28 & 3.14 & 0.83 & 0.46 & 0.00 & 4.71 & 9.00 \\
\hline 8 & 4.13 & 5.0 & 1.8 & 0.93 & 0.55 & 12.4 & 29.0 \\
\hline ND & & 7.25 & 0.00 & 2.0 & 0.61 & 9.86 & 24.23 \\
\hline ND & & 4.51 & 1.77 & 7.08 & 0.0 & 13.36 & 25.40 \\
\hline ND & & 6.66 & 4.57 & 0.43 & 0.11 & 11.77 & 17.73 \\
\hline ND & & 4.64 & 1.72 & 2.54 & 1.70 & 10.6 & 18.67 \\
\hline 18 & 4.31 & 2.09 & 0.35 & 0.21 & 1.22 & 8.18 & 24.18 \\
\hline \multicolumn{8}{|c|}{ Extension amount of Jiyang Depression (km) } \\
\hline 19 & 12.0 & 8.6 & 2.8 & & 1.6 & 25.0 & 33.0 \\
\hline 20 & 14.6 & 3.0 & 5.9 & & 0.8 & 24.3 & 44.5 \\
\hline 21 & 14.7 & 0.4 & 1.9 & & 0.4 & 17.4 & 27.1 \\
\hline 22 & 12.5 & 1.5 & 4.7 & & 2.7 & 21.4 & 42.8 \\
\hline \multicolumn{8}{|c|}{ Extension amount of Dongpu Sag $(\mathrm{km})$} \\
\hline 23 & & & & & & 6.90 & 28.91 \\
\hline 24 & & & & & & 11.80 & 34.01 \\
\hline 25 & & & & & & 13.50 & 33.00 \\
\hline
\end{tabular}

Seismic profile 1-8 from Tian \& Han (1990); 9-13 from Dong et al. (2013); 14-18 from Cao (2008); 9-22 from Xiao, Chen \& Li (2002) and Jiang et al. (2007); and 23-25 from Li \& Li (1994).

could be due to the fact that the extension in BBB has been calculated on seismic sections across segments of the basin, rather than the entire basin.

\section{5.c. Inversion structure analysis}

The mechanism responsible for the development of inversion structures in some parts of the Bohai Bay Basin during Cenozoic time is a matter of debate. This is mainly because evidence for inversion is not observed everywhere within the BBB, but only in some parts of the basin (namely in the Jizhong, Xialiaohe and Jiyang depressions). Based on interpretation of seismic sections of the Jizhong Depression, some authors concluded that the Maxi Fault at the foot of the Wenan Slope is a contemporaneous thrust fault which developed during deposition as result of gravity sliding (Yang \& Wang, 1985; Wang, 1988). The inversion structure in the Jiyang Depression has not been possible to verify from the published seismic data (Hou et al. 2009). Only those reverse faults which have developed locally in the Xialiaohe Depression (Figs 4, 5) are therefore recognized as 'typical' inversion structures, for example the Lengjia reverse fault ( $\mathrm{Li}$ et al. 2013; Qi et al. 2013) and the Rongxintun reverse fault (Chen et al. 2005). Some researchers (Zhao \& Windley, 1990; Allen et al. 1997; Hu, Wei \& Zhang, 2002; $\mathrm{Su}$ et al. 2009) have attributed this inversion to the
E-W compression caused by the conversion between the Australia and the Philippine Sea plates or IndiaEurasia continental collision. However, others (Chen et al. 2005; Ma, Qi \& Yu, 2005; Tong, Yu \& Geng, 2008; Li et al. 2010, 2013) related the inversion to dextral strike-slip movement along the Tanlu Fault.

Since inversion structures have been verified only in the Xialiaohe Depression, it is less likely that the BBB has been subjected to a full-scale inversion. Our interpretation of some of the available industry seismic profiles shows that Xialiaohe Depression has experienced two phases of inversion separated by an erosional episode (Fig. 5). Timing of the inversions is estimated based on thickness change of the sediments interpreted on seismic lines (Fig. 5). The first inversion phase, which seems to have been more rigorous, occurred during late Oligocene time (Ed reflectors in Fig. 5). MesozoicEocene (Mz and Es in Fig. 5) and upper Oligocene (Ed) units show clear evidence of this inversion. The $\mathrm{Mz}$ and Es units are folded, whereas lower to middle parts of Ed units are inverted along the boundary faults $F_{1}$ and $F_{2}$ (Fig. 5). This inversion phase must have resulted in local uplift and subsequent erosion. In the NE part of Xialiaohe Depression, the entire Ed and upper parts of Es units are eroded (Fig. 5), whereas SW of the Xialiaohe Depression Es units are preserved and only the upper parts of Ed units are eroded (Fig. 5). This variation in the degree of erosion indicates that 
the first phase inversion must have been more effective in the NE part of the Xialiaohe Depression (and/or that the SW part was a deeper basin before inversion). The erosion phase is followed by deposition of Neogene sediments ( $\mathrm{Ng}$ and $\mathrm{Nm}$ in Fig. 5). These units are inverted along the Taian-Dawa Fault $\left(\mathrm{F}_{1}\right)$ outlining the second phase of inversion in the Xialiaohe Depression from early Neogene time onwards. There is a substantial thickness change of Guantao and Minghuazhen formations ( $\mathrm{Ng}$ and $\mathrm{Nm}$ in Fig. 5) across the TaianDawa Fault $\left(\mathrm{F}_{1}\right)$. The intensity of this second phase of inversion also decreases towards the SW part of the Xialiaohe Depression (Fig. 5).

In Model 3, which was subjected to E-W compression after it was initially extended, inversion structures were observed in different parts of the model (Fig. 9). These results illustrate that the localized inversion in Xialiaohe Depression in the NE part of Tanlu Fault cannot be attributed to an E-W full compression. The interpretation of seismic profiles traversing the western sag of the Xialiaohe Depression shows that the inversion only developed within the boundary fault zone (Taian-Dawa $\left(F_{1}\right)$ and Lengjia $\left(F_{2}\right)$ faults, Fig. 5). The inversion, which decreases from NE to $\mathrm{SW}$, is overall subtle and is only visible along a few faults based on seismic interpretation.

The results of Model 2, where inversion was initiated by about $5^{\circ}$ anticlockwise rotation of the eastern block around a pole located in the SE, are compatible with the characteristics of the first phase inversion detected on seismic profiles. In this model, during rotation only the NE part which simulated the Xialiaohe Depression experienced inversion. In this model, the faults $\left(f_{3}\right.$ and $f_{4}$ ) bounding the basin were inverted and the deeper units accommodated the shortening by folding (Fig. 13). This is similar to inversion of preexisting normal faults in the Xialiaohe Depression and the folding of the lower Mz units (Fig. 5). In nature, this inversion mechanism can be due to the rotation of the eastern block of Tanlu Fault, possibly driven by the convergence of the Pacific Plate with the Eurasian Plate and the opening of the Japan Sea during 32$18 \mathrm{Ma}$ (Northrup, Royden \& Burchfiel, 1995; Allen et al. 1997).

In Model 1, which was subjected to a larger degree of rotation $\left(c .8^{\circ}\right)$, the boundary faults were inverted and new thrust faults formed and propagated beyond the inverted boundary faults (Fig. 13). However, regarding the Xialiaohe Depression such thrusts are not reported in the literature and have not been observed on the seismic profiles which we had access to. As such, it is concluded that inversion must have been local and of a limited intensity.

\section{5.d. Proposed new model for the Bohai Bay Basin}

Previous rifting models and inversion mechanisms do not satisfactorily explain the structural configuration of the Bohai Bay Basin. Simple NW-SE extension proposed by Ye et al. (1985) and Liu (1987) cannot explain the E-W-trending normal faults in the Bozhong and Jiyang depressions within the step-over part of the basin, or the major strike-slip faults in the NE and SW of the basin (Fig. 15). The result of Model 5 (Fig. 11), which simulated this tectonic scenario proposed by Ye $e t$ al. (1985) and Liu (1987), verified that NW-SE extension only generates NNE-trending normal faults both in the NE and SW zones and the central step-over area. The right-stepping ENE-trending transtensional fault zones formed along the northern and southern boundaries of Model 5 do not exist in the Bohai Bay Basin, where these boundaries are normal faults. In addition, the length $\left(L^{\prime}\right)$ to width $\left(W^{\prime}\right)$ ratio in the step-over area of Model $5\left(L^{\prime} / W^{\prime}=2.07\right)$ is much larger than the ratio $(L / W=1.30)$ of BBB. The width ratio in the NE and SW parts of Model $5\left(W_{1}{ }^{\prime} / W_{2}{ }^{\prime}=1.51\right)$ is smaller than the same ratio for those areas in the BBB $\left(W_{1} / W_{2}=\right.$ 1.92; Fig. 11).

Furthermore, the pull-apart model and its variations proposed by Klimetz (1983) and Hou, Qian \& Song (1998) neglect the presence of $50-100 \mathrm{~km}$ wide rift zones in the Xialiaohe and Jizhong depressions in the NE and SW of the basin (Fig. 1). The Cenozoic NWSE extension superimposed by the dextral strike-slip model proposed by Qi \& Chen (1992) cannot explain the $\mathrm{E}-\mathrm{W}$-trending normal faults in the centre of the BBB outlining the Bozhong and Jiyang depressions.

The transtension model proposed by Allen et al. (1998) and N-S extension model proposed by Zhou \& Zhou (2006) are similar to the model which we propose here. However, the model of Zhou \& Zhou (2006) does not account for the local inversion which occurred during late Oligocene - Miocene time. Allen et al. (1998) proposed a two-phase dextral transtension for the formation of the greater BBB. Our models support the N-S extension models of Allen et al. (1998) and Zhou \& Zhou (2006). However, our model results show that the basins can form in one transtension phase without the necessity for two phases of transtension. In addition, model results show that the documented inversion in the NE part of basin can be attributed to rotation rather than a full-scale shortening of the greater BBB. Anticlockwise rotation of the eastern margin of the BBB relative to its western margins around a pole located in the SE explains two main observations. It accounts for the local inversion which has been reported only in the NE segment of the BBB (Xialiaohe Basin) by for example Li et al. (2013) and confirmed by interpretation of seismic data in this study. As evident from seismic data, this inversion decreases in intensity from NE to SW along the Tanlu Fault (Figs 4, 5). An anticlockwise rotation is compatible with a dextral strike-slip movement along the Tanlu Fault which, during the rotation, must have had both dip and strike-slip movement, that is, oblique slip. Such 'local' oblique inversion is modelled for two localities in the Middle Polish Trough, where inversion was attributed to oblique movement along a major strike-slip fault: the Holy Cross Fault (Gutowski \& Koyi, 2007). Another significant feature which can be attributed to the rotation in the BBB is the extension 
that occurred in the SW part of the basin. At the same time (late Oligocene) as when the Xialiaohe Basin in the NE underwent inversion, the Dongpu Sag in the SW was undergoing extension. Seismic data show that $\mathrm{Ng}$ and $\mathrm{Nm}$ units are inverted along some of the faults in the Xialiaohe Depression in the NE. However, these units do not show any sign of inversion in the Dongpu Sag in the SW (Qi et al. 2006). A simultaneous inversion in the NE and extension in the SW is only possible during rotation along a pole in the SE. This element is clearly demonstrated in the models presented here, where rotation of the eastern block around a pole in the SE led to shortening of the basins in the NE and further extension in the SW basins of the model.

Based on modelling results and seismic profile interpretation, we propose a tentative model for the evolution of the BBB (Fig. 16). During Paleocene (65 Ma) early Oligocene time, the Kongdian (Ek) and Shahejie (Es) formations and the second member of Dongying Formation were deposited in the grabens and halfgrabens generated by the roughly $\mathrm{N}-\mathrm{S}$ extension. During late Oligocene time, the NE part of BBB was inverted while the SW part (Dongpu Sag) was extended due to anticlockwise rotation around a pole in the SE. This rotation could be due to convergence between Pacific and Eurasian plates. An erosion phase which preceded the inversion created a widespread Neogene unconformity throughout the BBB. However, erosion was most intensive in the inverted Xialiaohe Depression (Yu et al. 2007, 2015). After erosion, the BBB underwent uniform thermal subsidence accompanied by a second inversion phase during Miocene-Pliocene time (from $\mathrm{Ng}$ to $\mathrm{Nm}$ formations).

\section{Conclusions}

Based on our interpretation of reflection seismic data and the results of scaled analogue models, the following conclusions are drawn about the evolution of the Bohai Bay Basin.

1. The Cenozoic evolution of the BBB can be divided into three stages: (1) Paleocene - early Oligocene transtension; (2) late Oligocene rotation accompanied by the first phase of inversion and regional erosion; and (3) thermal subsidence accompanied by a second inversion phase during Miocene-Pliocene time. This last episode is deduced from seismic interpretation, but not simulated in the models.

2. Transtension was due to roughly $\mathrm{N}-\mathrm{S}$ extension (with the angle of $25^{\circ}$ between the extension direction and the strike-slip fault boundary) which occurred during Paleocene - early Oligocene time.

3. Inversion seen mainly in the NE part of the BBB (Xialiaohe Depression) was probably due to regional rotation of the eastern block of the BBB around a pole in the SE. Such rotation can account for synchronous inversion in the NE and extension in the SW (Dongpu Sag), which was probably driven by the subduction of the Pacific Plate beneath the Eurasian Plate during 32$18 \mathrm{Ma}$.
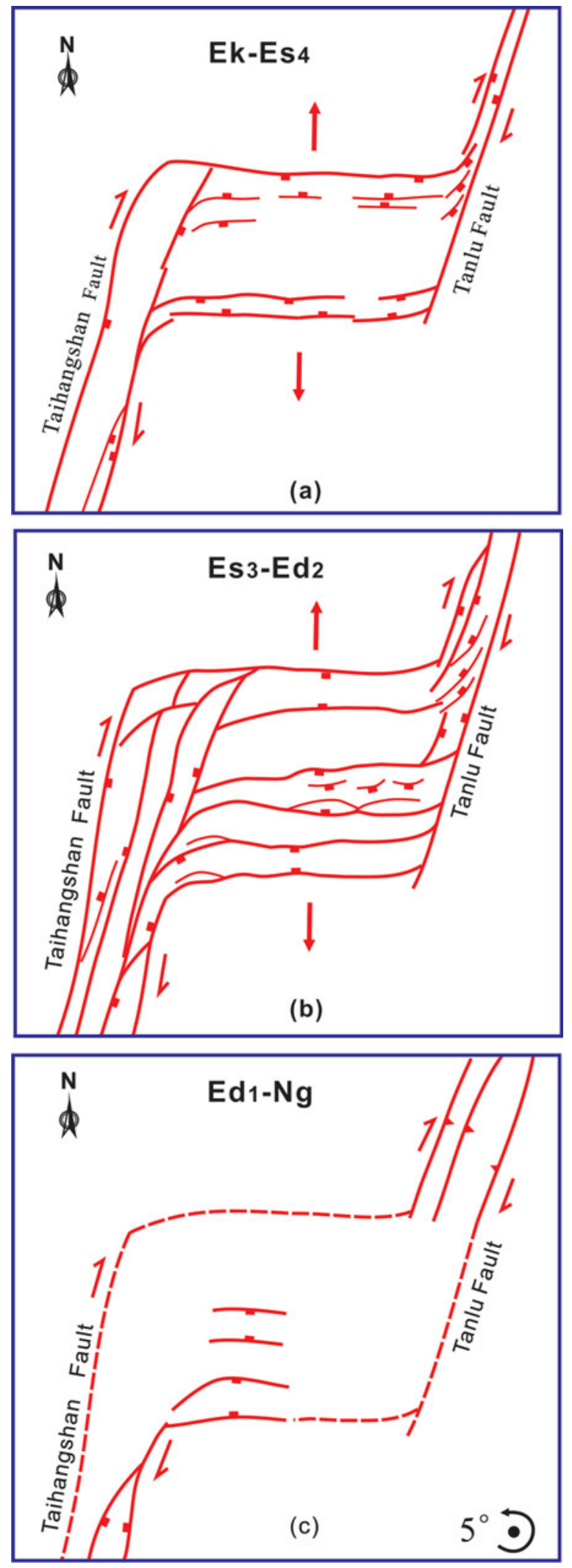

Figure 16. (Colour online) Schematic evolution model showing the sequence of events in the BBB based on results of Model 1. (a-c) Line drawings of mapview of Model 1: (a) Ek-Es 4 transtension; (b) $\mathrm{Es}_{3}-\mathrm{Ed}_{2}$ transtension; and (c) inversion stage $\left(\mathrm{Ed}_{1}-\mathrm{Ng}\right.$ anticlockwise rotation and inversion). Note in (c) the compression structures in the NE and extension structures in the SW during rotation. 
Acknowledgements. This study was funded by the National Natural Science Foundation of China (grant nos 41472116, 41372116) and the Jidong Oil Company of China National Petroleum Company (grant no. 20150081). We acknowledge the Liaohe Oil Company of CNPC for providing the seismic profiles. HK is funded by the Swedish Research Council (VR). This study was carried out during a one-year sabbatical of FY at the Hans Ramberg Tectonic Laboratory (Uppsala University). Constructive and detailed comments of Giacomo Corti improved both the content and presentation of this article. Comments from a second anonymous reviewer are also acknowledged.

\section{References}

Allen, M. B., Macdonald, D. I. M., Xun, Z., Vincent, S. J. \& Brouet-Menzies, C. 1997. Early Cenozoic twophase extension and late Cenozoic thermal subsidence and inversion of the Bohai Basin, northern China. Marine and Petroleum Geology 14, 951-72.

Allen, M. B., Macdonald, D. I. M., Xun, Z., Vincent, S. J. \& BRouet-MenzIES, C. 1998. Transtensional deformation in the evolution of Bohai Basin, northern China. In Continental Transpressional and Transtensional Tectonics (eds. R. E. Holdsworth, R. A. Strachan \& J. F. Dewey), pp. 215-29. Geological Society of London, Special Publication no. 135.

Brace, W. F. \& Kohlstedt, D. L. 1980. Limits on lithospheric stress imposed by laboratory experiments. Journal of Geophysical Research 85, 6248-52.

CAO, Z. X. 2008. Calculation of extension and subsidence of the Cenozoic pull-apart and rift basins along the Yingkou-Weifang fault zone. Chinese Journal of Geo$\operatorname{logy}$ 43(1), 65-81 (in Chinese with English abstract).

CHANG, C. Y. 1991. Geological characteristics and distribution patterns of hydrocarbon deposits in the Bohai Bay Basin, east China. Marine and Petroleum Geology 8, 98-106.

Chen, H. L., YAng, S. F., JiA, C. Z., Sun, H. B. \& Cheng, X. G. 2005. Origins of Cenozoic reverse faults in northeastern China: an example from the Rongxintun fault in the Liaohe basin, China. Journal of Asian Earth Sciences 25, 167-72.

Chen, S. P., Zhou, X. H., TANG, L. J., WANG, Y. B., LU, D. Y, Sun, M. S. \& QU, D. M. 2010. Wrench-related folding: A case study of Bohai Sea basin, China. Marine and Petroleum Geology 27, 179-90.

Chen, W. P. \& NABELEK, J. 1988. Seismogenic strike-slip faulting and the development of the North China basin. Tectonics 7, 975-89.

CORTI, G. 2012. Evolution and characteristics of continental rifting: analog modeling-inspired view and comparison with examples from the East African Rift System. Tectonophysics 522-3, 1-33.

DONG, M., QI, J. F., YANG, Q. \& YUAN, F. 2013. Characteristics of extension amounts and their temporal and spatial distribution of the Cenozoic of Huanghua Depression in Bohai Bay Basin. Journal of Paleogeography 15(3), 327-38 (in Chinese with English abstract).

Feng, Y. L., ZhoU, H. M., ReN, J. Y., ZhenG, H. R. \& MiAO, S. D. 2010. The Paleogene stratigraphic sequences and its response to tectonic activities in the eastern part of Bohai Bay basin. Science in China Series D: Earth Sciences 40(10), 1356-76.

Gong, Y. L., Wang, L. S., LiU, S. W., Li, C., Han, Y. B., LI, H. \& CAI, J. G. 2008. Distribution of temperature at the bottoms of Cenozoic source rocks in the Bohai
Bay Basin. Chinese Journal of Geology 43(1), 1-11 (in Chinese with English abstract).

Guo, H., Xia, B., Chen, G. W., Wang, R. H., Ding, J. H., WANG, J. J. \& HUANG, T. 2005. Geochemistry of basalts during Oligocene in Huimin depression and its geotectonic significance. Geotectonica et Metallogenia 29(3), 303-15 (in Chinese with English abstract).

GuO, L. Z., MA, R. S., ShI, Y. S., LU, H. F., ZHU, W. B., ZHANG, Q. L., SHU, L. S. \& JIA, D. 1998. On the generation and evolution of Mesozoic-Cenozoic backarc basins of western Pacific active continental margin. Journal of Chengdu University of Technology 25(2), 134-44 (in Chinese with English abstract).

Guo, X. W., ShI, X. B., QIU, X. L, Wu, Z. P., YANG, X. Q. \& XIAO, S. B. 2007. Cenozoic subsidence in Bohai Bay basin: characteristics and dynamic mechanism. Geotectonica et Metallogenia 31(3), 273-80 (in Chinese with English abstract).

GUTOWSKI, J. \& KOYI, H. A. 2007. Influences of oblique basement strike slip faults on the Mesozoic evolution of the SE segment of the Mid-Polish Trough. Basin Research 19, 67-86.

HaO, F., Zhou, X., ZhU, Y., Zou, H.Y. \& Yang, Y. 2010. Charging of oil fields surrounding the Shaleitian uplift from multiple source rock intervals and generative kitchens, Bohai Bay basin, China. Marine and Petroleum Geology 27, 1910-26.

HE, H. Q., WANG, Z. Y. \& HAN, P. L. 1998. Tectonic control on the formation and distribution of oil-gas pools in the Bohai Bay Basin of North China. Acta Geologica Sinica 72(4), 313-22.

Hoshino, K., Koide, H., Lnami, K., Lwarmura, S. \& MitsuI, S. 1972. Mechanical Properties of Japanese Tertiary Sedimentary Rocks Under High Confined Pressure. Geological Survey of Japan Report no. 244. $200 \mathrm{pp}$.

Hou, G. T., QIAN, X. L. \& CAI, D. S. 2001. The Tectonic evolution of Bohai Basin in Mesozoic and Cenozoic time. Acta Scientiarum Naturalium (Universitatis Pekinensis) 37(6), 845-51 (in Chinese with English abstract).

Hou, G. T., QIAN, X. L. \& Song, X. M. 1998. The origin of the Bohai Bay Basin. Acta Scientiarum Naturalium (Universitatis Pekinensis) 34(4), 503-9 (in Chinese with English abstract).

Hou, X. B., WU, Z. P., LI, W. \& YU, H. Z. 2009. Tectonic positive inversion of Chennan Fault and its relation with hydrocarbon accumulation in Dongying Sag. Journal of Daqing Petroleum Institute 33(6), 25-9 (in Chinese with English abstract).

HSiaO, L. Y., GRAHAM, S. A. \& Tilander, N. 2004. Seismic reflection imaging of a major strike-slip fault zone in a rift system: paleogene structure and evolution of the Tan-Lu fault system, Liaodong Bay, Bohai, and offshore China. AAPG Bulletin 88, 71-97.

HSIAO, L. Y., GRAHAM, S. A. \& TILANDER, N. 2010. Stratigraphy and sedimentation in a rift basin modified by synchronous strike-slip deformation: southern Xialiaohe basin, Bohai, offshore China. Basin Research 22, 6178.

Hu, C. Y. 1982. Geodynamic environment of Bohai gulf basin and its oil occurrence. Experimental Petroleum Geology 4(3), 161-7 (in Chinese with English abstract).

Hu, S. B., PAul, B., O’Sullivan, A. R. \& BARRY, P. K. 2001. Thermal history and tectonic subsidence of the Bohai Basin, northern China: a Cenozoic rifted and local pullapart basin. Physics of the Earth and Planetary Interiors 126, 221-35. 
HU, W. S., WEI, Y. J. \& ZHANG, Z. Q. 2002. Inverted structural characteristics of Liaohe Basin. Journal of Xi' an Petroleum Institute (Natural Science Edition) 17(5), 5-13 (in Chinese with English abstract).

Huang, H. P. \& PeArson, M. J. 1999. Source rock palaeoenvironments and controls on the distribution of dibenzothiophenes in lacustrine crude oils, Bohai Bay basin, eastern China. Organic Geochemistry 30, 1455-70.

JACKSON, J. A. \& White, N. J. 1989. Normal faulting in the upper continental crust: observations from regions of active extension. Journal of Structural Geology 11, $15-36$.

JiANG, S. H., XU, X. M., KANG, H. M., WANG, Z. Y. \& WANG, P. 2007. Analysis of Cenozoic tectonic subsidence history and wave cycle in Huimin Depression. Journal of Oil and Gas Technology 29(5), 1-7 (in Chinese with English abstract).

KLIMETZ, M. P. 1983. Speculations on the Mesozoic plate tectonic evolution of Eastern China. Tectonics 2, 13966.

KoYI, H. 1997. Analogue modelling; from a qualitative to a quantitative technique, a historical outline. Journal of Petroleum Geology 20(2), 223-38.

KOYI, H. 2001. Modelling the influence of sinking anhydrite blocks on salt diapirs targeted for hazardous waste disposal. Geology 29(5), 387-90.

KOYI, H. \& PETERSON, K. 1993. Influence of basement faults on the development of salt structures in the Danish Basin. Marine and Petroleum Geology 10, 82-94.

Koyi, H. \& Vendeville, B. C. 2003. The effect of decollement dip on geometry and kinematics of model accretionary wedges. Journal of Structural Geology 25, 1445-50.

LI, D. S. 1980. Geology and structural characteristics of Bohai Bay, China. Acta Petroleum Sinica 1(1), 6-18 (in Chinese with English abstract).

LI, D. S. \& XUE, S. H. 1980. The eastern China MesozoicCenozoic basins and hydrocarbon occurrence. Acta Geological Sinica 3, 224-34 (in Chinese with English abstract).

LI, L., ZHAO, L., LIU, H. J. \& FANG, X. Y. 2015. Late Mesozoic to Cenozoic extensional and strike-slip structures and deep background of Bohai Bay basin. Chinese Journal of Geology 50(2), 446-72 (in Chinese with English abstract).

LI, M. G., QI, J. F., TONG, H. M., YU, F. S. \& WanG, N. J. 2010. Cenozoic fault structure and hydrocarbon accumulation in Western Sag, Liaohe Depression. Petroleum Exploration and Development 37(3), 281-8 (in Chinese with English abstract).

LI, P. J. \& LI, D. S. 1994. A study on the extensional structures of Dongpu sag. Petroleum Exploration and Development 21(4), 6-9 (in Chinese with English abstract).

LI, P. J., LU, H. F. \& SHI, Y. S. 1995. Study on the formation and fault structures of the Dongpu depression of Bohai gulf, eastern China. Journal of Nanjing University (Natural Sciences Edition) 31(1), 128-39 (in Chinese with English abstract).

Li, Z. G., JiA, D., CHEN, W., ZhANG, Y. K., WANG, M. M., LI, Y. Q., LI, H. B. \& LI, S. Q. 2013. Structural deformation and evolution of right-lateral strike-slip tectonics of the Liaohe western depression during the early Cenozoic. Journal of Asian Earth Sciences 77, 1-11.

LIU, C. Y. 1988. The reproduction of Paleo-structure and the establishment of equilibrium profile for extension structure area. Experimental Petroleum Geology 10(1), 33-43 (in Chinese with English abstract).
LIU, G. D. 1987. The Cenozoic rift system of the North China Plain and the deep internal process. Tectonophysics 133, 277-85.

LIU, G. D. \& LIU, C. Q. 1983. Structures of crust and upper mantle and their relation to Cenozoic tectonism in northern part of North China. Scientia Sinica (Series B) 26, 550-60 (in Chinese with English abstract).

LIU, M., CUI, X. J. \& LIU, F. T. 2004. Cenozoic rifting and volcanism in eastern China: a mantle dynamic link to the Indo-Asian collision? Tectonophysics 393, 29-42.

MA, B. J., QI, J. F. \& YU, F. Y. 2005. Physical modelling on the inversion structures in the west sag of Liaohe depression. Journal of Oil and Gas Technology 27(1), 142-5 (in Chinese with English abstract).

MA, X. Y., LIU, G. D. \& SU, J. 1984. The structure and dynamics of the continental lithosphere in north-northeast China. Annals of Geophysics 2, 611-20.

MA, X. Y., LIU, H. F., WANG, W. X. \& WANG, Y. P. 1983. Meso-Cenozoic Taphrogeny and extensional tectonics in eastern China. Acta Geologica Sinica 1, 22-31 (in Chinese with English abstract).

MAILlOT, B. \& KoYI, H. 2006. Thrust dip and thrust refraction in fault-bend folds: analogue models and theoretical predictions. Journal of Structural Geology 28, 36-49.

Mann, P., Hempton, M. R., Bradley, D. C. \& Burke, K. 1983. Development of pull-apart basins. Journal of Geology 91, 529-54.

MCKENZIE, D. 1978. Some remarks on the development of sedimentary basins. Earth and Planetary Science Letters 40, 25-32.

Molnar, P. \& TAPPONNIER, P. 1975. Cenozoic tectonics of Asia: effects of a continental collision. Science 189(4201), 101-122.

NABELEK, J., CHEN, W. \& Ye, H. 1987. The Tangshan earthquake sequence and its implications for the evolution of the North China basin. Journal of Geophysical Research 92, 12615-28.

Northrup, C. J., Royden, L. H. \& BurChFiel, B. C. 1995. Motion of the Pacific plate relative to Eurasia and its potential relation to Cenozoic extension along the eastern margin of Eurasia. Geology 23, 719-22.

QI, J. F. 2004. Two tectonic systems in the Cenozoic Bohai Bay basin and their genetic interpretation. Geology in China 31(1), 15-22 (in Chinese with English abstract).

QI, J. F. \& CHEN, F. J. 1992. Structural style in LiaodongXialiaohe Basin. Oil \& Gas Geology 13(3), 272-83 (in Chinese with English abstract).

QI, J. F., DenG, R. J., ZHOU, X. H. \& ZHANG, K. X. 2008. The structure of Tanlu fault zone in the Cenozoic of the Bohai Bay basin. Science in China Series D: Earth Sciences 38(suppl), 19-29 (in Chinese with English abstract).

QI, J. F., LI, X. G., YU, F. S. \& YU, T. C. 2013. Cenozoic structural deformation and expression of the TanLu Fault Zone in the West Sag of the Liaohe Depression, Bohaiwan basin province, China. Science China: Earth Sciences 43, 1324-77 (in Chinese with English abstract).

QI, J. F., LU, K. Z., ZhANG, Y. W., YANG, Q. \& CHEN, F. J. 1995a. Relationship between tectonics and hydrocarbon in Bohai Basin province. Journal of the University of Petroleum China 19(suppl), 7-13 (in Chinese with English abstract).

QI, J. F., Wang, D. R., Chen, S. P., ZhaO, Y. B., Cheng, X. S., XIE, C. \& XU, Z. Q. 2006. Impact of geometry and kinematics of Lanliao Fault on structural styles in Dongpu Sag. Oil and Gas Geology 27(4), 451-9 (in Chinese with English abstract). 
QI, J. F. \& YANG, Q. 2010. Cenozoic structural deformation and dynamic processes of the Bohai Bay basin province, China. Marine and Petroleum Geology 27, 757-71.

QI, J. F., YANG, Q., CHEN, F. J. \& CHEN, Z. N. 1994. Kinematic characteristics and evolution of the Cenozoic tectonics in Liaodongwan-Xialiaohe basin. Geoscience 8(1), 3442 (in Chinese with English abstract).

QI, J. F., ZHANG, Y. W., LU, K. Z. \& YANG, Q. 1995b. Cenozoic tectonic evolution in Bohai Bay basin province. Journal of the University of Petroleum China 19(suppl), 1-6 (in Chinese with English abstract).

QI, J. F., ZHANG, Y. W., LU, K. Z. \& YANG, Q. 1995a1995c. Extensional pattern and dynamics process of the Cenozoic rifting basin in the Bohai Bay basin. Experimental Petroleum Geology 17(4), 316-23 (in Chinese with English abstract).

QI, J. F., ZHOU, X. H. \& WANG, Q. S. 2010b. Structural model and Cenozoic kinematics of Tan-Lu deep fracture zone in Bohai Sea area. Geology in China 37(5), 1231-42 (in Chinese with English abstract).

REN, F. L., LiU, Z. Q., QIU, L. G., HAN, L. G. \& ZhoU, L. 2008. Space-time discrepancy of depression evolution in the Bohai Bay Basin during Cenozoic. Chinese Journal of Geology 43(3), 546-57 (in Chinese with English abstract).

SCHELlART, W. P. 2000. Shear test results for cohesion and friction coefficients for different granular materials: scaling implications for their usage in analogue modelling. Tectonophysics 324, 1-16.

SCHELlarT, W. P. \& Lister, G. S. 2005. The role of the East Asian active margin in widespread extensional and strike-slip deformation in East Asia. Journal of Geological Society, London 162, 959-72.

Su, J. B., ZHU, W. B., Lu, H. F., Xu, M. J., YANG, W. \& ZHANG, Z. Y. 2009. Geometry styles and quantification of inversion structures in the Jiyang depression, Bohai Bay Basin, eastern China. Marine and Petroleum Geo$\log y$ 26, 25-38.

TIAN, Z. Y. \& HAN, P. 1990. Extensional analysis on the Bohai faulted basin and its hydrocarbon potentiality. Acta Petrolei Sinica 11(2), 1-12 (in Chinese with English abstract).

TIAN, Z. Y. \& HAN, P. 1991. Structural deformation analysis and the depressing mechanism of Bohai basin. Journal of Hebei College of Geology 14(1), 1-18 (in Chinese with English abstract).

TIAN, Z. Y., HAN, P. \& XU, K. D. 1992. The MesozoicCenozoic East China rift system. Tectonophysics 208, 341-63.

Tong, H. M., Yu, F. S. \& GENG, C. B. 2008. Characteristics and evolution of strike-slip tectonics of the Liaohe Western Sag, Bohai Bay Basin. Petroleum Sciences 5, 223-9.

WANG, T. H. 1986. Evolution of Meso-Cenozoic stress field and the formation of buried hill hydrocarbon pools in Bohai Bay basin. Oil and Gas Geology 7(3), 274-80 (in Chinese with English abstract).

WANG, T. H. 1988. Genetic types of thrust faults in eastern China petroliferous regions. Earth Science-Journal of China University of Geoscience 13(6), 627-34 (in Chinese with English abstract).

WEIJERMARS, R., JACKSON, M. P. A. \& VENDEVILlE, B. 1993. Rheological and tectonic modelling of salt provinces. Tectonophysics 217, 143-74.

XIAO, H. Q., CHEN, G. J. \& LI, C. B. 2002. Basin extensional amount of the Jiyang depression and its petroleum geological significance. Petroleum Geology and Experiment 24(1), 13-19 (in Chinese with English abstract).
XU, J., GAO, Z. W., SUn, J. B. \& SonG, C. Q. 2001. A preliminary study of the coupling relationship between basin and mountain in extensional environments: a case study of the Bohai Bay basin and Taihang Mountain. Acta Geologica Sinica 75(2), 165-74 (in Chinese with English abstract).

YANG, K. S. \& WANG, T. H. 1985. Contemporaneous thrust fault in Jizhong depression and its significances in petroleum exploration. Petroleum Exploration and Development 4, 1-7 (in Chinese with English abstract).

YANG, Y. T. \& XU, T. G. 2004. Hydrocarbon habitat of the offshore Bohai basin, China. Marine and Petroleum Geo$\log y$ 21, 691-708.

Ye, H., Shedlock, K. M., Hellinger, S. J. \& Sclater, J. G. 1985. The North China Basin: an example of a Cenozoic rifted intraplate basin. Tectonics $\mathbf{4}$, 153-69.

Ye, H., Zhang, B. T. \& MaO, F. Y. 1987. The Cenozoic tectonic evolution of the Great North China: two types of rifting and crustal necking in the Great North China and their tectonic implication. Tectonophysics 133, 217 77.

YIN, A. 2000. Mode of Cenozoic east-west extension in Tibet suggesting a common origin of rifts in Asia during the Indo-Asian collision. Journal of Geophysical Research 105, 21745-59.

Yu, F. S., Ji, Z. W., Yang, X., Yu, Z. Q., Ma, B. J. \& ZHANG, L. J. 2007. Cenozoic fault feature and trap styles of northern area in west depression of Liaohe Basin. Journal of Earth Sciences and Environment 29(2), 149153 (in Chinese with English abstract).

YU, F. S., Dong, Y. X., TONG, H. M., XIONG, L. Q. \& LonG, X. 2015. Characteristics and origins of structural deformation in the Paleogene in the Western Sag of Liaohe Depression, Bohai Bay Basin. Oil and Gas Geology 36(1), 51-60 (in Chinese with English abstract).

Zhang, J. D., HaO, T. Y., Dong, S. W., Chen, X. H., Cui, J. J., YANG, X. Y., LIU, C. Z., LI, T. J., XU, Y., HuANG, S. \& REN, F. L. 2015. The structural and tectonic relationships of the major fault systems of the Tan-Lu fault zone, with a focus on the segments within the North China region. Journal of Asian Earth Sciences 110, 85-100.

ZHANG, Q., QIAN, Q., WANG, E. Q., WANG, Y., ZhaO, T. P., HaO, J. \& GUO, G. J. 2001. An East China Plateau in Mid-Late Yanshan Period: implication from adakites. Scientia Geologica Sinica 36(2), 248-55.

Zhang, Y. Q., Ma, Y. S., YANG, N., SHI, W. \& Dong, S. W. 2003. Cenozoic extensional stress evolution in North China. Journal of Geodynamics 36, 591-613.

ZHAO, Z. Y. 1984. Structural pattern and evolution of Bohaiwan basin, China. Acta Petrolei Sinica 5(1), 1-8 (in Chinese with English abstract).

ZHAO, Z. Y. \& WINDLEY, B. F. 1990. Cenozoic tectonic extension and inversion of the Jizhong Basin, Hebei, northern China. Tectonophysics 185, 83-9.

ZHOU, J. X. \& ZHOU, J. S. 2006. Dynamics of Cenozoic simulation in Bohai basin: physical simulation and discussion. Science in China Series D: Earth Sciences 36(6), 507-19 (in Chinese with English abstract).

Zhou, T. W., ZhOU, J. X., DONG, Y. X, WANG, X. D. \& CHANG, H. W. 2009 Formation mechanism of Cenozoic fault system of NanPu sag in Bohai Bay basin. Journal of China University of Petroleum 33(1), 12-7 (in Chinese with English abstract).

ZhU, G., JiANG, D. Z., ZHANG, B. L. \& CHEN, Y. 2012. Destruction of the eastern North China Craton in a backarc setting: Evidence from crustal deformation kinematics. Gondwana Research 22, 86-103. 